\title{
Christ at Large
}

"The moment was actually during the violence," Jhon explained when I said I was interested in the pictures that had arisen in Ambon's streets,

when the faith of us believers, us Christians was shaking-many people fled from Ambon ... so we thought even if it is only a picture, a painting, we were always convinced that he was here. ... Back then, the situation was really hot, so we imagined this spontaneously. We wanted to ensure that God would really and truly be present in the conflict. We wanted to do this even though the city was burning on all sides, but we were convinced God was here. So I painted while Ambon was in flames, God on clouds. And this is truly what we think: if you figure it, Christians in Ambon should already have been done with. Just imagine what we had here-what kind of weapons did we have? We had nothing. We only had bombs that we made out of bottles. When they went off they sounded like firecrackers. ${ }^{1}$

A year later, I returned to the Christian neighborhood where Jhon lived to spend more time talking with the motorbike-taxi drivers as they hung around their stand waiting for customers. My argument in this chapter draws especially on fieldwork in 2005 and 2006 , but it also moves between different temporalities-from the time of the war and recollections of the violence, as in the passage above, to the postwar circumstances in which such recollections took place. The paintings themselves straddle these distinct temporalities, since in the mid-2ooos many that had been done during the conflict continued to be touched up or repainted in the immediate years thereafter. 
Facing a large mural depicting canonical scenes from Christ's life, the men spoke to me about what they claimed was the city's first picture to have been produced during the war-a hijacked billboard showing Jesus looking down on Ambon and the surrounding Malukan islands that stood next to the mural facing their bike stand. The most talkative among them recalled:

During the conflict in Ambon Christians were slaughtered by Muslims. We took the decision to do this picture even as the Muslims were attacking us. We took the decision with Jhon who is a youth from here. Jhon said, "Why don't we paint Jesus blessing Ambon here?" The guys liked the idea because Jesus blesses Ambon so that we feel close to God. Lord Jesus cries as he looks down on Ambon City. He cries to see the suffering of the community of Ambon City. Long ago we lived happily, but now we kill each other. ${ }^{2}$

Another account of the Protestant turn to picturing comes from a GPM council member who described how his church commissioned a Christ reaching out with extended arms from behind the altar as early as 1999 or during the conflict's first year:

There was a general atmosphere of panic and fear, so this was done to strengthen the faith so that people would know that God was always here. People had the feeling that God was not here. Violence was all around. Fires were everywhere. The picture was [intended] to provide the assurance that God is with us-that he lifts us up. Faith was still shaky. ${ }^{3}$

Sammy Titaley, a prominent Protestant minister and the GPM synod head during the conflict, offered a theologically more grounded explanation that similarly draws a connection between the street pictures' emergence and a surge in faith afflicted by crisis among the city's Christians:

I think this was done only to channel the conviction that God was here, because according to us what kind of appearance does God have? Is the image of God like a photo? It's not, right? But if there were a photo ... So, now what emerged was the desire to make God visible. Whatever God is, a man, we don't know. Maybe it could be a woman. And what kind of face would she/he have? Also that we don't know. But because of the enthusiastic flaring up of faith, he wanted to paint as if this was the God he worshiped. And he did not care if in the street our young people sometimes thought, "So what if we die." So because of this whatever they did-painting, singing-all of this was actually a form of expression, an expression of faith. ${ }^{4}$ 
Insisting on God's presence during the conflict-he was here-along with the desire to ensure such presence in circumstances in which "faith was shaky," was a recurrent theme in the interviews, casual conversations, and passing exchanges I had with Christians in Ambon in the mid-2ooos-besides painters, motorbikers, and Protestant ministers, also local journalists, ordinary women and men, the occasional aid worker, and in sermons in GPM churches. Echoing the statements I heard in the streets, for instance, the repeated reassurance that "God is here, you must not doubt, he is loyal," punctuated a minister's sermon one Sunday morning in July 2006 in the Maranatha church. As such, it is just one example of how church officials repeatedly invoked God's unwavering presence amid the difficulties besetting wartime and postwar Ambon and, beyond the city, the myriad disasters afflicting Indonesia in the mid-2ooos-from volcanic eruptions and the spread of HIV/AIDS to the 2004 tsunami. ${ }^{5}$

Not everyone was as taken by the street productions as the above excerpts from my field notes and recordings suggest. Given that they signaled a highly public departure from the aniconic tradition of the Calvinist church, this is hardly surprising. But other attitudes were also relevant, especially the GPM clergy's evaluation of the young men who supported the pictures and put them in place. They ranged from people like Minister Titaley who welcomed them as "expressions of faith" to others who voiced their concern that the behavior of the motorbikers in the vicinity of the pictures might not correspond to what they considered Christian. Jhon, for instance, described to me some of the opposition he faced as a street painter but then quickly cast aside any criticism by insisting on the overwhelming need to demonstrate that Jesus "really, really is here, he is here":

"Why are you painting in the streets? You are just wasting time" [is how some people challenged him]. There were certainly some who spoke like that. There were. At the office they also got mad at me because I didn't show up for work. Occasionally because I was tired from painting I did not go into work. I was tired. I would work until morning using a lamp. Until morning. And if I was sleepy in the morning I would not go into work. But this is only because sometimes there are those in favor and those who are against, some who do not approve and think, "Hey, what are you doing painting Jesus in the streets?" But while some thought Jesus was not here, you have to think that Jesus is here, and make him large so that all can see it. Once and a while people think what are these pictures for, but we have to show that Jesus really, really is here, he is here, you must not be doubtful, you must not, that is the objective. But once and a while, people have an understanding that is different, one that is not the same as our own. We are people of God. 
We want what is good, so that all people can see this. Sometimes people are that way but in general people liked the pictures. ${ }^{6}$

During the conflict, not only was Christ present, he was present in particular ways. Jhon's recollections of the billboard on which he painted Jesus overlooking Ambon on a Sampoerna cigarette advertisement suggest that key elements in ensuring the Christian God's presence were scale, visibility, and an omniscient ordering gaze:

When I paint, I paint large-scale, on the walls of homes, the same on ceilings. In the big houses - great houses - of businessmen, on the ceiling, angels then God at the center with angels all around him. His origin, his origins are those angels, right? Previously, you know, there was another picture of ascension. Birth, death, resurrection, ascension. The picture of that ascension is already ruined, that is the one we made like an advertisement, so we raised it up high, higher than all the other images because of his being on high. We used his face, we raised it up high, using supports, scaffolding. So it was like an advertisement, we raised it up high, so we pictured him up on clouds so that was high.

Jhon further underscored the importance of the street pictures' visual appeal akin to that of the billboard ad that his painting of the ascension had covered over: "They should be pleasing to look at," he added, "and be able to be seen from a distance." Part of this appeal lies in how the painting provides a perspective, a reassuring, all-seeing presence capable of being seen from a distance overlooking and apart from the chaos of war.

But in addition to Christ's appearance on billboards and murals, he was repeatedly sighted in the city during the war-emerging in different places around Ambon, bearing arms on urban battlefields-and more far-flung even in Manado, a provincial capital at the northeastern tip of Sulawesi Island that harbored many Christians who fled the violence in Maluku. There, in the summer of 2001, Christ's face darted across a chapel wall, appearing and disappearing and drawing crowds who hoped to see it. Minister Titaley explained:

Here is an example. During the Time of Violence, many people saw images of Jesus appear on walls. There were people who saw this and there were those who did not. ["What do you mean they did not see this?" I asked.] It was not visible, like that. It was not seen but there were people who said, "It is there, and there, and over there," like that. But it was not seen. What emerged were apparitions. His face appeared. Before that there was even an image of Jesus that bled, in 
Manado. But in Ambon we just saw images, images of his face. In Benteng, in . . . almost everywhere. I went to look but I never saw them. People asked me, "Pak is this true or not?" I said to them, "Let us not say this is true or not true, let us not say that they lie." Because it is possible, and when an image appeared almost all of Ambon went to look. And it also made people afraid; they did not like it. The image of Jesus. Everyone went to look. At the time I was in Namlea [on the neighboring island of Buru], so because of this I did not know about it. There was one that appeared in Dobo [the capital of the Aru Islands in Southeast Maluku], in the church. The minister back then was a woman. There was violence in Dobo. Then it appeared again, following the violence in Dobo. In the church but also in houses. In Benteng it was not in the church but in a pigsty. It also appeared in Gonzalo up there among the Catholics. Many people asked, "Where? Where? Where?" They could not see it. But it was seen before violence, it was seen during violence, it was seen after violence, so people were afraid_-"What if this means there will be violence again?"

Another way that Christ was at large, if equally immersed in the violence, was as a war commander. Rather than a frightening apparition auguring violence's onset, Christ surfaced in the midst of fighting, where he was seen striding forth into battle leading the Christians against the Muslims. Here, again, is Minister Titelay:

There were many stories that circulated, right? Saying that there was a white commander among us, a large man with shoulder-length hair. He was seen everywhere. Those who wanted to kill him never could. Shooting at him was like shooting at the wind. He appeared everywhere-in Tanah Lapang Kecil, all over, as far as Seram he appeared. Over there in Poka Rumah Tiga he appeared. They [Muslims] said, "Christians are afraid. They are using a commander from Europe, a Westerner, a foreigner." His hair was shoulder-length, long. People said this is Jesus, right! Among those people who spoke about this were also soldiers. [He appeared] in the midst of violence, during the conflict. Because of this I always say, "Believe it or not!" [in English]. Never before did he come like that. So this is why I often say, "A kind of miracle, no?" [English]. Actually this should be written about in books. There were even some people who came especially from Malaysia when they heard about this, they came to check it out. Office girls from Jakarta, Malaysians. I say just ask the kids in the street, go around and ask them to tell you about it. They all can tell the story. ${ }^{9}$ 
Christ was on the move, elusive and mobile, appearing here, there, and "everywhere" during the war, if not to everyone. In Manado he drew crowds hoping to spot his face migrate across chapel walls, he led Christians into battle in city streets, and showed up in a pigsty in a Catholic neighborhood above Ambon. Surfacing in the thick of violence, his apparition and especially his face measured out violence's duration-prefiguring its onset, marking its direction, haunting its aftermath. Emerging frequently against the backdrop of a cross, the tormented Christ face of crucifixion folded his martyrdom into the general suffering of Ambon's Christians.

I quote at some length here in order to convey the tenor of the conversations I had with Christians about the street paintings and to highlight a few themes. Noteworthy are the desperation and terror that drove the impulse to make the pictures: statements that their "faith was ... shaking," that "people had the feeling that God was not here," that "Christians were [being] slaughtered by Muslims," and that "Christians in Ambon should already have been done with," for example. Noteworthy also is the sense of God's estrangement, the wavering of faith in a burning city, and the lack of any defensive mechanism to fall back on: "What kind of weapons did we have? We had nothing." But also, how Christ at large in the city articulated a dynamic among different manifestations-on the one hand, he was immersed in violence where his fleeting appearance acted as a harbinger of violence and caused fear, on the other, his painted appearance on billboards and murals situated him here in Ambon as an empathetic figure arising above the fray.

My interest is in understanding the insistence on God's presence across diverse settings and how such presence materialized monumentally on sidewalks, along highways, in homes, behind altars, and at Christian neighborhood gateways. But also, the qualification voiced by at least some GPM Protestants that the billboards and murals were, of course, "just pictures." Minister Titelay's position is more ambivalent, echoing the dynamic outlined above. Although he characterized the street pictures as welcome "expressions of faith," casting them nonetheless as epiphenomenal vis-à-vis the more primary phenomenon of religion, he also called them "apparitions," miraculous and ungraspable like the wind. The latter attitude comes closer to the adamant insistence on God's presence often heard in the streets insofar as it complicates any dismissal of the new popular medium as mere portrayals of Christian themes modeled after familiar print originals. It also points to an unresolved tension surrounding the Christian paintings as to whether they acted as efficacious presences, bringing God into vision and enabling physical and emotional identification and interaction with him (something I take up in Chapter 3) -in short, behaving like devotional images - or whether they were only neutral, uninterested surfaces 

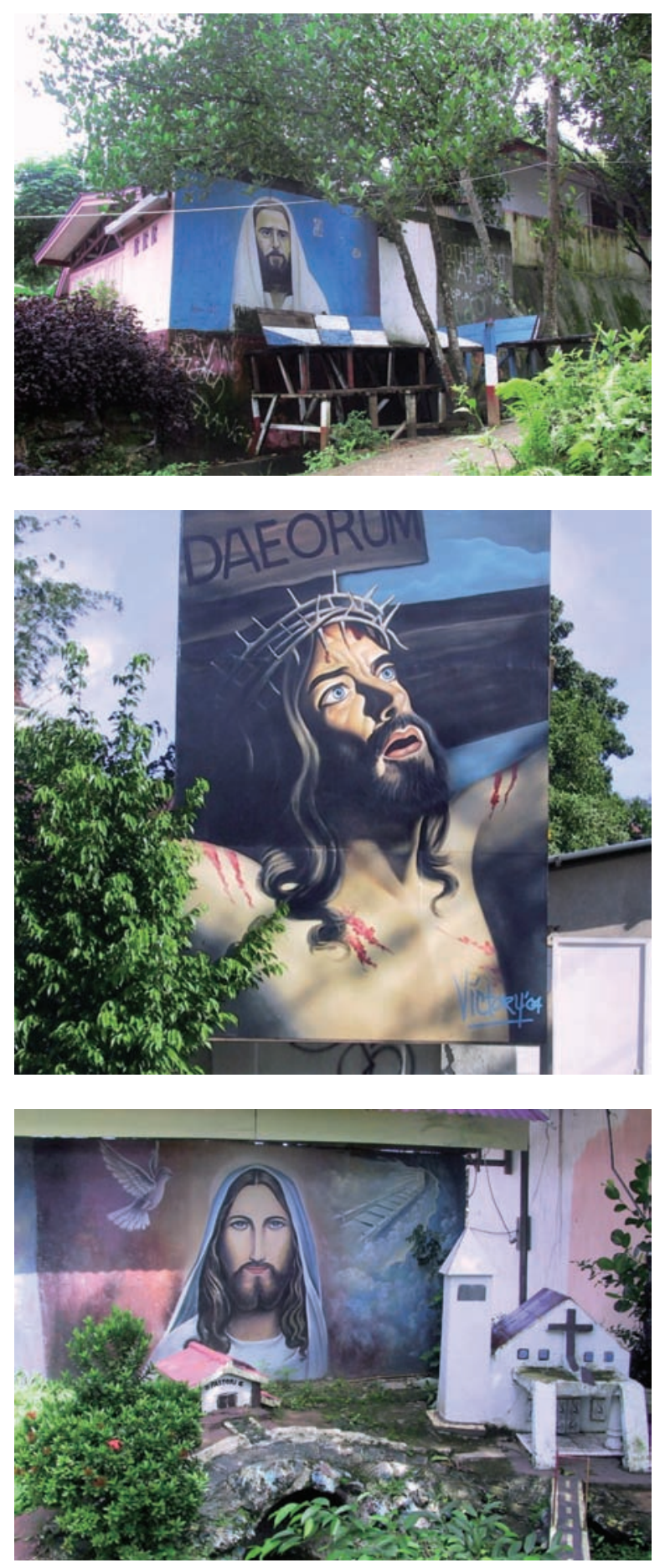

Figure 7. Murals and billboard paintings of Jesus Christ, Ambon, 2005 and 2006 . Photos by the author. 

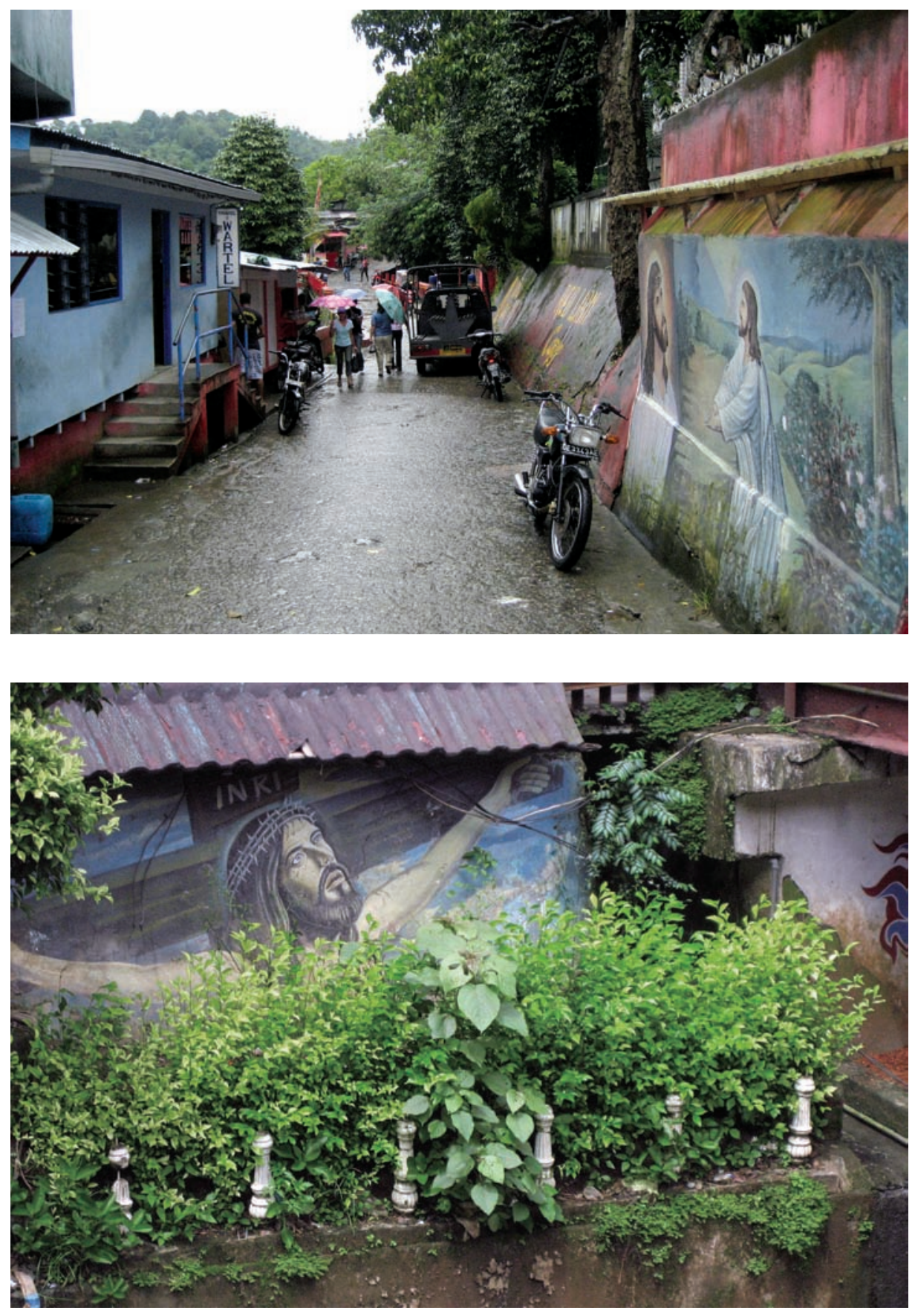
easily assimilable to canonical Protestant attitudes about images. ${ }^{10}$ An enormous sense of precarity regarding the position of Protestants in Ambon and around Indonesia fed this dynamic, one that comes through in the frequent claims about how faith was on the wane and fragile, or how some people felt that God was either not here or that he needed to be brought close, suggesting, at the least, that the Christian deity was somehow drifting or distracted. Put otherwise, I am interested in the coming-into-vision of Christ in Ambon City but also in the anxious uncertainty surrounding his appearance, in the nagging sense that God might not be watching over the city's Christians, that rather than being in situ, here in Ambon, he was disturbingly at large in an increasingly precarious and threatening world.

\section{Christ at Large}

The commentary offered by Ambonese on these images and the production and spread of the pictures themselves all beg the following question: When did the Christian God begin to appear inaccessible via the ordinary means available to his followers? When did he begin to appear so absent that a picture of him-albeit "just a picture"-needed to be put in place to offer the assurance that he really and truly was here, always here? To paint pictures and embrace them in the calamitous, edgy environment of the war was to experiment in certain desperation, to launch a new medium in the hope that it might engage and moor the Christian God who appeared elusive or at least too far away to provide the necessary solace. But this God was not simply absent or out of reach. At large in what Minister Titaley called the "Time of Violence," he was also insistently present. He was "here, there, and everywhere," manifest as a fugitive figure visible to some but not to others-a transitory apparition moving across walls, sighted in a pigsty, passing through or announcing violence that unfolded in full brutality around him. In the context of these extraordinary times, a number of young men took the decision to paint Jesus looking down on the suffering in Ambon City from a billboard facing their motorbike stand. Alternating paintbrush with prayer, this painting and the others that proliferated during and after the war bear poignant testimony to a vast effort to bring God in intimate connection with the world, to visually pinpoint and circumscribe his location here overlooking the violence that cast a thick cloud over Ambon and severely taxed religious faith. Rather than caught up in the violence like the Ambonese, he is pictured at a close, comforting distance, on a larger-thanlife scale high up on clouds and surrounded by angels. This perspective that repeats itself across the street paintings helps to diminish the conflict, making 
it picturable and seeable to God's eye in contrast to the all-encompassing horrific, murky realities on the ground.

To assess the creativity of the drive to picture as well as that of the pictures themselves, it is worth considering the discontinuities that mark this newly invented practice. At stake in these dramatic times was the articulation of a desire and a force that was daring, experimental, and aggressive-hence, not just the urgency that drove the pictures' production but also the undeniable energy with which they sprung up and spread across the city. For what the pictures bear witness to and helped to put in place was nothing less than the imagination of something quite different from what had been seen beforeperhaps most radically in the sense of figuring a novel mode of mediating transcendence or accessing the Christian God by bringing him into view and close. Sites of experimentation in more than a few respects, the paintings break with the past and, specifically, with the antimaterialist, aniconic tradition of Ambon's Dutch-derived Calvinist church, the GPM, and they are assertive in the new publicness they accord to religion-although certainly not alone in this in Indonesia after Suharto (see Chapter 4). So, too, are they radical in seizing upon the traveling images of a globalized Christian print capitalism and in the inspiration the new artisanal practice found in the range of other materials around. Daring, also, are the city's Christian images in their envisioning of myriad mise-en-scènes as the possible loci of new understandings of community and in their visualization of heterotopias that potentially transport those who engage their effects beyond the discursive frames of the Indonesian state and its codified forms of citizenship or those inherited from its predecessor, the Dutch colonizer (see Chapter 3). They are radical as a new medium of expression and communication-socially, politically, aesthetically, and spiritually. Last but not least, they are novel in their self-organizing capacity - no church or other institution or authority rallied around or pushed the production of the images. ${ }^{11}$

Yet, while radical in so many ways, not the least in the brute fact of their physical presence around the city, in other respects these picturing projects were quite nostalgic, especially in their positing of a visual public that excludes anything incompatible with a wholly Christian universe. Constituting what might be called a postwar poetics of world-making, what these pictures want is to repair and restore the everyday lifeworlds of a previolent moment when Ambonese Christians still, by and large, enjoyed relative power and privilege. ${ }^{12}$ They were world-making, too, in their dramatic sense of arrival and in the novelty with which they stood out from the ruins of the recent war and forced themselves into public view. Put simply, this world-making condensed two 
distinct temporalities - the first is evident in the obligatory, recuperative reiteration of Christ's face across myriad productions. The second is more openended, future-oriented, and, in some respects, disoriented. I refer here to the wildly experimental backdrops to the Christ figure and face that I mention occasionally in this chapter but address more fully in the next. Admittedly, this division between foreground and background is heuristic since the two not only function together but the former, while stereotypical, is also unstable and may, in some respects, be equally described as lacking orientation. This chapter focuses more on the globalized Christian iconographic canon, how it became articulated and transformed in Ambon's streets and infused by the energies and passions of the young men who supported them. Chapter 3 introduces the painters and homes in closely on different pictures and clusters of pictures, exploring both their diversity and their similarity in bringing the Christian God into vision and close to Ambonese.

Both this chapter and the next are concerned with the paintings and the environments in which they arose-how, through graphic means, the street pictures aimed to put in place and restore the appearance of a city that, through the early 1990s, had a decidedly "Christian impression about it."13 Through a nostalgic form of representational redress, the pictures reinstated the public visibility that Ambon's traditional Protestants had long taken for granted as an everyday aspect of their entitled, state-authorized position - at least locally and regionally in Central Maluku. The formulation "representational redress" was coined in the context of postapartheid South Africa to designate the progressive process of "re-figuring who we are but also how we define our future sociospatial and political relations." "I4 Although driven by similar concerns in Ambon, and notwithstanding the considerable innovation of the street pictures, the urge to refigure who we are and how we can ensure our future was not progressive but restorative and bent on self-preservation. In a somewhat perverse take on poetic world-making, Christian Ambonese aimed to seize hold of a disappearing world, one that upheld their historically accumulated privileges, not the least the Christian domination of the city and provincial civil bureaucracy, including prize positions like that of Maluku's governor. ${ }^{15}$ Via the pictures, they recalled a world that faithfully reflected back to them its reassuring Christian contours in sociospatial and political terms and, through these, the image that the Protestants had long held of themselves. This is an embattled vision, one that looks to the past and relies on and recasts old iconographies, albeit necessarily in innovative ways.

Put otherwise, the concerted work on appearances undertaken in Ambon's streets was inflected by the desire to (re)institute a sociopolitical order and distribution of the sensible with a decidedly Christian appearance, one that 
sustained Protestant Ambonese privileges, assumptions, and sense of place. Articulated through the visual medium of painting, this work may be seen as yet another manifestation of the extreme perception that developed during the war along with the anticipatory practices that I described in the previous chapter. More pragmatically, amid the conflict's zoning of urban space and its many displacements, hijacking billboards and spraying Christian scenes and symbols along public sidewalks and walls claimed territory for the Christians as Christ's visual presence Christianized the public space around them. Equally importantly, although impossible to determine with any precision, the rise of the street pictures paralleled but seems also to have partially preceded the dramatic redeployment of religion during the war and the changes in religious affiliation, practice, and experience that characterized this redeployment-to which, significantly, the pictures contributed. Among other noteworthy transformations in urban religion, as I discuss in Chapter 4, were the significant numbers of Protestants who abandoned the GPM for charismatic churches in search of a less hierarchical, more intimate relation to God in contrast to the distant, fatherly figure of Calvinism.

\section{The Canon in the Street}

Notwithstanding their dramatic appearance, a striking feature of the paintings scattered around the city was their essential restorative impulse. To be sure, the pictures were inevitably striking and, in many respects, experimental, if nothing else because of their immense size. I refer instead to the intentions that drove their production and their insistent reiteration of the globalized, if locally conventional, Christian iconography. With only a few exceptions, the handful of artists who I worked with around the city, some more than others, set out to reproduce rather than change or reform the images that they borrowed from the Christian iconographic canon familiar to them as Protestant Ambonese. Regularly, on my stopovers at the motorbike stands, and especially when I visited the painters in their homes or, in the case of the most commercially minded among them, at his roadside studio, I would come upon the painters engaged in their artistic work. Almost always, on such occasions, a book would lie open next to them on the floor or a page torn from a Christian calendar or magazine would be taped alongside or tucked behind the canvas, showing illustrations drawn from Euro-American examples. More often than not, these Christian scenes focused on the figure of Christ in the guise, for instance, of a shepherd with a flock of sheep, a pilgrim pausing before a house door, or Jesus praying in profile at Gethsemane or up on clouds with angels. People who commissioned painters often described to me the models they had 
provided-for instance, a minister mentioned the "photo" of Gethsemane from the Christian magazine Gloria that had inspired the design of the small prayer room in his home, a GPM council member recalled the calendar image of Christ of the Second Coming that he had asked Jhon to reproduce in his church, while the larger than life angel on the exterior wall of a Christian home was similarly copied from a calendar, the kind given out by Christian stores around the Christmas holiday (Figure 8). Again and again, traveling in and around Ambon in the mid-2ooos, I saw copies of the same Christian printderived pictures: for example, the kneeling angel in a Halong home was the same as another in Belakang Soya, although painted by different men; the billboard of a gentle, brown-eyed Christ in front of the Maranatha church and the portrait-size Jesus hanging in a Christian home reproduced the same image of the German painter Heinrich Hofmann, whose religious body of work, dating from the late nineteenth and early twentieth centuries, has been reproduced widely (Figure 9). His Christ in Gethsemane, seen on walls around Ambon, is one of the most copied paintings in the world.

Apart from the repetition of the global Christian print repertoire, there was also a brisk two-way traffic between the canonical print imagery and apparitional forms, especially during the war. Christ's common depiction as a European derives, Ambonese often remarked, not only from the pictorial examples provided in church and schools but from his own occasional appearance to them. If rumors circulated of Christ arising as a white commander upon the city's battlefields, in a more direct translation of the apparitional into the pictorial, an Ambonese with a gift of prophecy engaged a painter to commit his visions to canvas, resulting in a large triptych, dated ten days before the conflict began, that forecasts Ambon's apocalyptic destruction (Chapter 3). ${ }^{16}$

Notwithstanding such spectacular examples, what most characterized the traffic in Christian images was, again, repetition-repetition that involved interchanges, substitutions, and replicas within a canon of images and variations thereof. No strict divide, in other words, walled off the apparitional from print media or separated dreams, apparitions, and prophetic visions from print models and their painted reproductions. Indeed, these myriad image forms seemed to cycle seamlessly into each other-making any strict adherence to an aniconic ideology that asserts pictures are "just pictures" difficult to sustain. A short example will suffice. Following a minister's injunction to his son one morning before church to imagine Christ's face while praying, this face arrived repeatedly to haunt the family throughout the remainder of the day. During a nap following church, the minister's wife had a dream in which Christ appeared to her-first, she explained, as identical to a framed print of Jesus's head that hung before us in her home as she described to me her vision and, subsequently, 

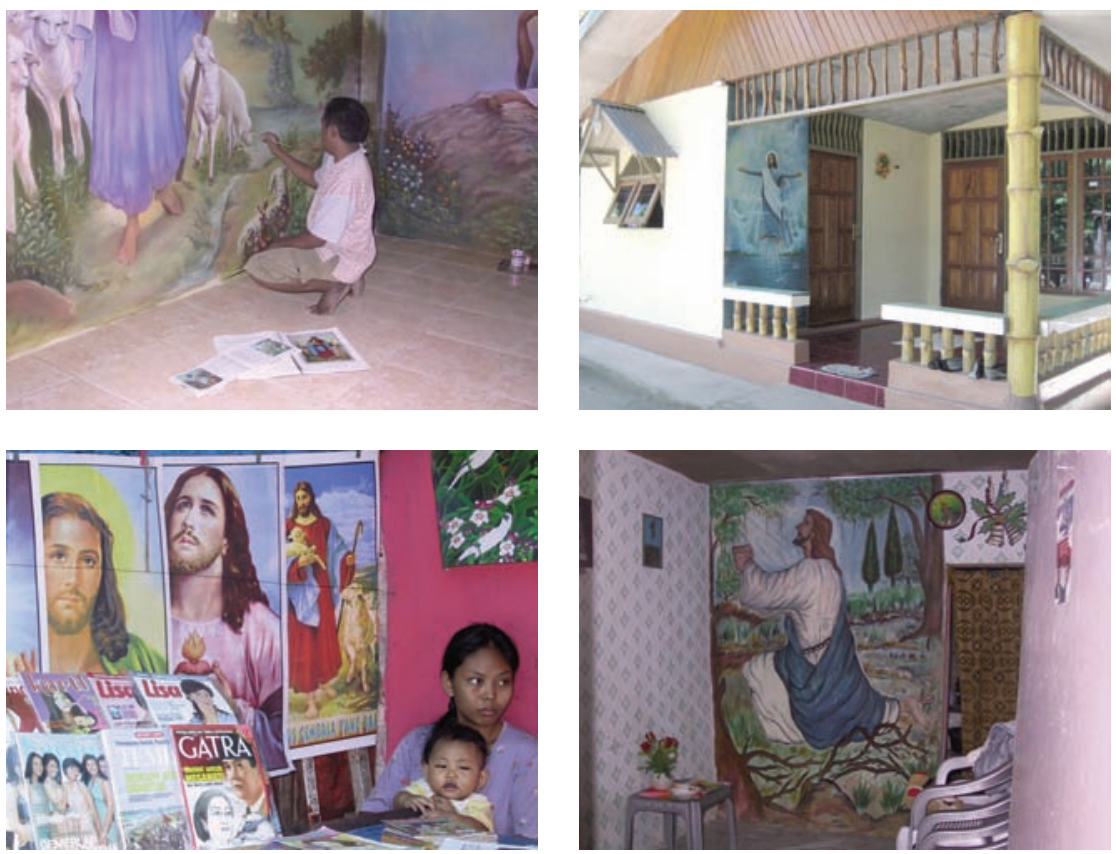

Figure 8. The painter Jhon Yesayas working on a mural of Christ as shepherd with the print images he is copying from on the floor beside him. Walls depicting Christ in Christian homes and market stall with posters that are a common source of inspiration. Ambon, 2005 and 2006. Photos by the author.

in the guise of another print she recalled in which he appeared with a bare torso and emanating light. In the minister's wife's account of her experience, these mediated appearances surfaced, in turn, in two additional appearanceseach an exact replica of the other-in the form of framed prints of Jesus in the homes of two families of the minister's congregation that she and her husband visited that day. What is more, a widow in the second home the minister and his wife stopped by that Sunday owned two prints corresponding to the first apparition, which, I was told, had appeared to the widow in the exact form as it had to the minister's wife. One of those prints, a gift by the widow to the minister's wife, also hung before us at the time of the interview. ${ }^{17}$

What stands out in this account is not only the reproducibility but also the sheer force of Christian mass print culture, as well as the emphasis on its dominant mediating role. Also noteworthy is the insistence on Christ's face, on the light rays radiating from his head-which the minister's wife evoked for me by pulling her hands repeatedly out from her head-and the role of print media as a visual currency in the reproduction of the GPM community. 

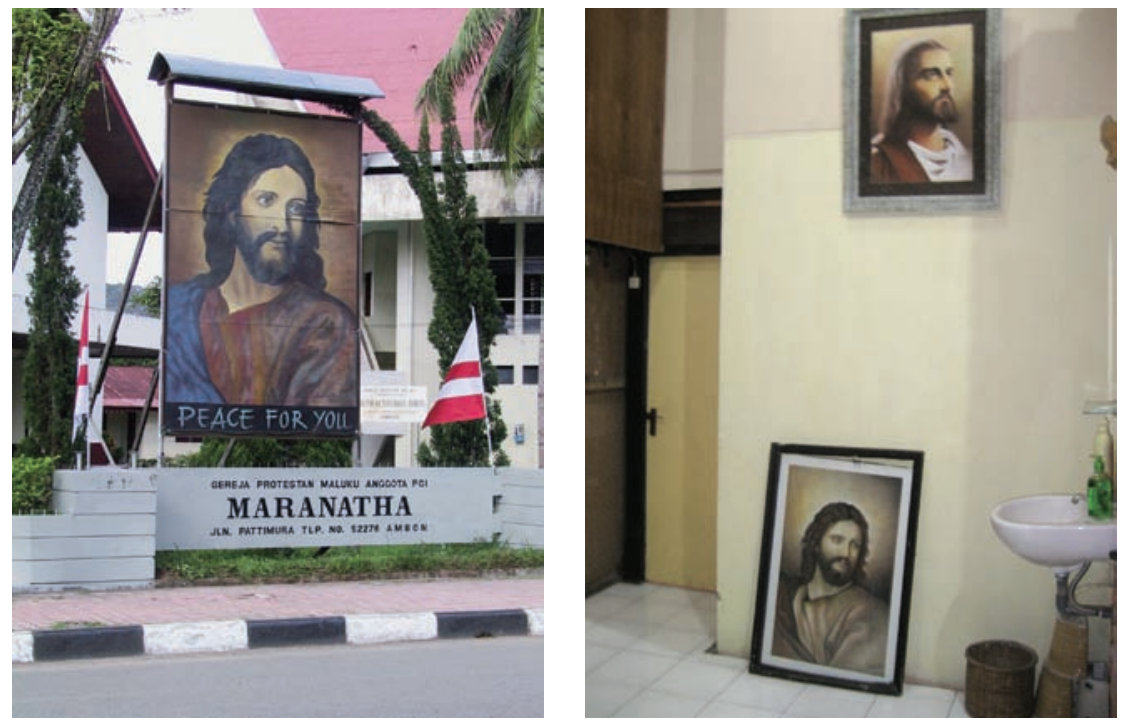

Figure 9. Painted billboard in front of the Maranatha church based on Heinrich Hofmann's painting Christ at 33, Ambon, 2003. And a home with framed images of a Warner Sallman and a Heinrich Hofmann Christ, hanging on the wall and propped up against it, respectively, Ambon, 2006. Photos by the author.

Notwithstanding the uncanniness of her experience, one wonders if the Calvinist insistence that pictures are "just pictures" does not also intervene in this particular case, given that what the minister's wife claims she saw was not or at least not conclusively Lord Jesus but a proliferating series of print renditions of him.

The majority of the pictures around the city drew on calendars and illustrated books that featured the work of the American painter Warner Sallman, whose paintings of Christ were a crucial component of popular religiosity and Christian visual culture from the mid-twentieth century, especially in the United States. Repeatedly, in Ambon I saw such Sallman classics as Head of Christ (1940), Christ at Heart's Door (1940), The Lord Is My Shepherd (1943), and Christ in Gethsemane (1941) both precisely and more approximately rendered. ${ }^{18}$ To a somewhat lesser extent, Heinrich Hofmann's Christs were also popular. Such models provided a steady reference, a source of inspiration, and even control for the painters' work, as they tended to delimit the kinds of pictures that could be made. Experimental and daring as they also surely were, representationally they largely remained tethered to the Christian print canon. It would be a mistake, therefore, to understand the artistry in Ambon's streets or behind church altars in conventional creative terms. From this perspective, 
the question posed by Jhon to the motorbikers manning the stand at the edge of his neighborhood-"Why not paint Christ blessing Ambon here?"-should especially be understood as an effort to visualize the Christian God as an empathetic figure watching over the city as opposed to indebted to any decorative impulse or understanding of painting as creative expression alone.

A canon presumes a delimited, knowable, and, in the Christian case at least, somewhat orderly visible world. When the world is more or less in place, the appearance of things and the actions of one's fellows correspond to common expectations: persons and objects moor each other in predictable ways, enabling the canon to unfold its conventional images in an environment where family, churches, community, and polity are more or less in place to receive them. When, by contrast, the world falls apart, the canon may succumb to unprecedented pressures, especially in circumstances where the visual is a focus of attention and under revision, as it was in Indonesia generally during Reformasi and even more in Ambon for reasons that I analyze in this book. In such circumstances, what images want becomes frustrated, since their correspondence to the world no longer applies. ${ }^{19}$ Put otherwise, they can no longer count on the frames that hitherto sustained them. In such moments of intensified desire and frustration, pictures may come out, bursting from their frames, becoming assertive and monumental, demanding new forms to satisfy their needs. ${ }^{20}$ Under such conditions, the provisional connection that pertains between canonical images or, for that matter, any image world and the world for which the images were made can become strained. Different possibilities may arise. Under duress, the canon may be abandoned or the images that comprise it may assume new forms as these are reworked and extended in new directions. The profound materiality of such images then comes to the fore-as evidenced in Ambon, for instance, by the aggressive encroachment of Christian pictures on public, urban space, by their exaggerated, blown-up proportions, and by the way they "filled the sight by force."21 Hence, notwithstanding the restorative urge that largely drove them, the ways the pictures strained and adapted to the canon's frames and experimented on city walls demonstrate their world-making capacity.

If Orphaned Landscapes is about the work on appearances, then it is also about how appearances do not work. Evidence of the latter can be found in the constant adjustments made to the canon to ensure that the pictures addressed the circumstances around them, especially the plight of the Protestants and the sense prevalent among them during the war that not only they themselves but their everyday existence was under siege and even at risk of annihilation. The first adjustment was the Protestants' own pictorial turn involving not only an embrace of pictures but, with it, a significant departure from the 

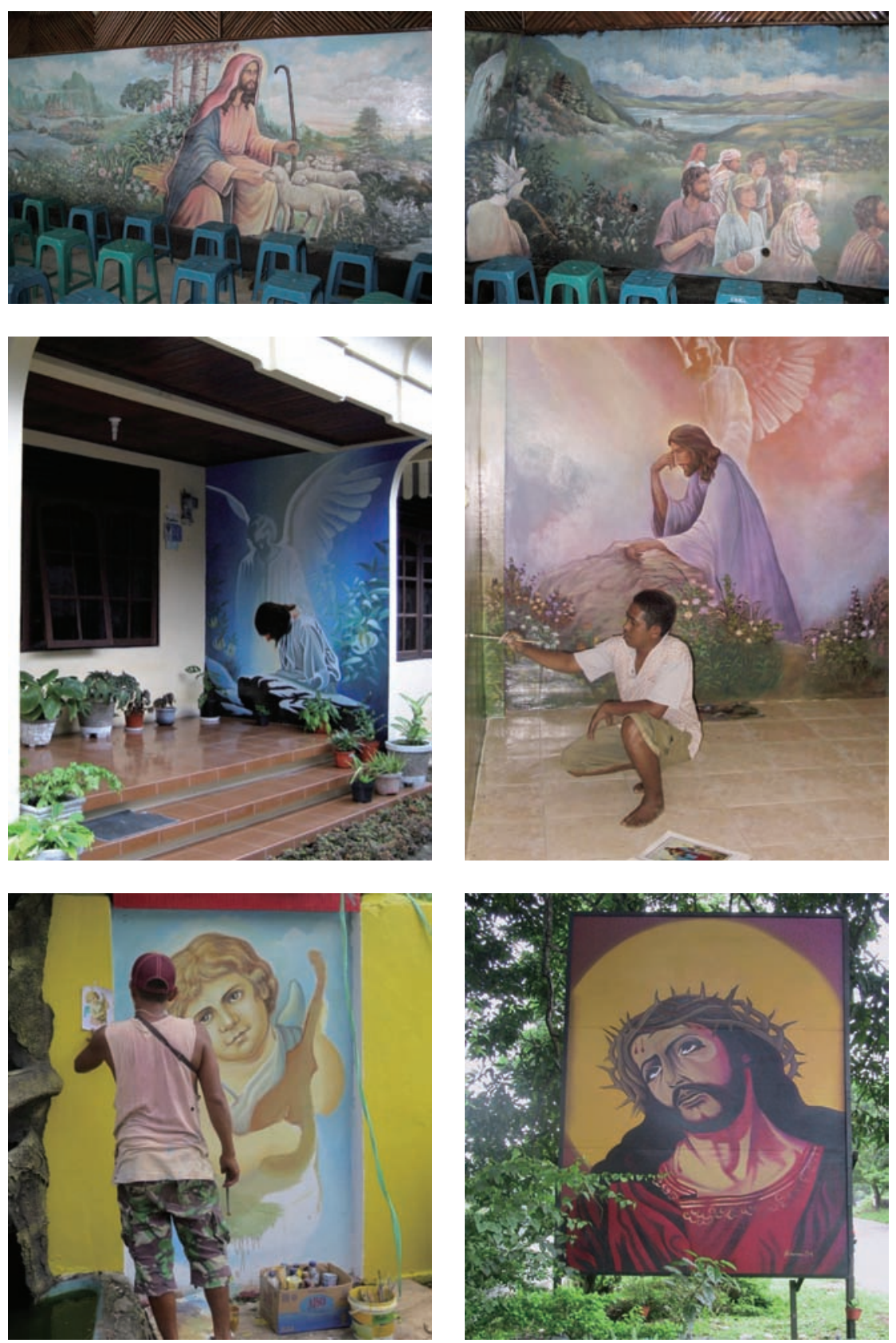

Figure 10. Christ images on the walls of a church assembly room, in private homes, and on a billboard along the highway into Ambon. The mural of a cherub playing a musical instrument signals a noticeable departure from the centrality of Christ in the Christian street art of the early 2000 s. Ambon, 2005, 2006, and 2016. Photos by the author. 
aniconic tradition of the Calvinist Protestant Church. Admittedly, before the war, calendars and, to a lesser extent, posters and embroidered or mother-ofpearl inlaid Christian scenes were conventional props of Christian homes and stores. Such elements of decor, together with Sunday school manuals, are a familiar component of the global Christian print repertoire that has long been available in Ambon. Confined to interior spaces, they seem not to be subject to the kinds of restrictions on images that existed in the GPM churches. Yet, if the Christian sacred was never invisible or faceless in the city, prior to the war it was-visually at least-not a privileged focus of attention, public or otherwise.

Of course, in Ambon as elsewhere, and notwithstanding Calvinism's antimaterialist ideology, transcendence unavoidably relies on mediation. Writing of mediation, Hent de Vries, a philosopher of religion, underscores its intrinsic, enabling role given that "without and outside of [it] . . . no religion would be able to manifest itself in the first place."22 But this is precisely what makes religion vulnerable, since mediation means that religion is always already subject to the risks, contingencies, limits, and translations that the material world presents to human desires and schemes. ${ }^{23}$ If already the case in ordinary circumstances, the vulnerability of religion at large in the world becomes enhanced in conditions marked by crisis and dramatic change, as in Ambon at the turn of the century. At stake then was much more than religion's regular vulnerability on account of its unavoidable material mediation. Rather, it was the anxious if also enthusiastic adoption of a new medium driven by the Protestants' desire to ensure God's presence and draw him close via his image.

Despite the long history of Dutch-derived Calvinism in the area, Ambon's Protestantism and that of the wider region were never as adamantly aniconic as that of their former colonial masters. ${ }^{24}$ Around Maluku, other traditions of materiality and ritual performance remained operative; indeed, some of these witnessed a significant revival during the war (see Chapter 5). National practices such as the requisite display of photographic portraits of Indonesia's president and vice president in government offices and public buildings (which in Ambon were populated predominantly by Protestants) perhaps had an impact as well. In a more intimate register, Indonesia's citizen's identity card (I. Kartu Tanda Penduduk), with its obligatory ID photograph and declaration of adherence to one of the five world religions recognized by the Suharto state, seems also to have been refracted in some of the street pictures, as we will see below. ${ }^{25}$ Besides the commercial advertisements for things like cigarettes, cell phones, and English-language and computer classes strategically positioned around the city, there were the faces and party affiliations of local political candidates that proliferated with regional autonomy and state-produced genres like maps and posters of married couples in ethnic dress standing in for Indonesia's 
unified diversity decorating government offices and classroom walls. ${ }^{26}$ During the New Order, billboards that translated the Suharto state fetish of "development" into visual form-happy, uniformed students, white-coated scientists, and planned families (with the slogan "Two children, That's enough!")-were seen all over the archipelago. ${ }^{27}$ Others showcased the regime's endorsement of the five world religions it recognized. The more temporary banners suspended over main thoroughfares in the postwar city announced university registration dates, competitions in marching, disco dancing, and the increasingly popular Muslim fashion shows, but also propaganda put out by the police and occupying armed forces mimicking-usually poorly-Ambonese Malay language and calling out for anything from postwar reconciliation and peace to proper garbage disposal. ${ }^{28}$ In today's visually crowded world, all sorts of image flows, visual modalities, and discourses - the density and diversity of which augmented during Ambon's war-converged upon, were taken up or discarded, and fragmented in different ways in the postwar environment. ${ }^{29} \mathrm{I}$ address these visualities and their multiple divergent perspectives in Chapter 3.

Along with the Protestants' turn to pictures, a second, related adjustment made to the canon was the effort to bring the Christian God close, something that, necessarily, involved significant iconographic departures from the canon as, for instance, Christ was depicted, in an unprecedented manner, hovering over Maluku or in situ in Ambon and the surrounding islands. Besides the teary-eyed Jesus looking down on a globe turned to Maluku on a billboard, his head floats over the destruction of the GPM's landmark Silo Church on a canvas where tiny white-clad jihadis engage khaki-colored National Army soldiers in battle; on another he extends his arms to refugees fording a river as they escape violence on neighboring Seram; on yet another he appears as an indigenous Malukan with dark skin and curly black hair, in a clear departure from the Euro-American iconographic canon centered on a white Christ. Not negligibly, bringing the Christian God into vision and up close also meant bringing oneself into view-via the church at which one worships, the islands where one resides, the portrayal of one's wartime predicament or that of fellow Christians similarly caught up in violence, or as Christ in the image of an Ambonese.

Commenting on these pictures, local painters occasionally recalled how they abandoned the canon's iconographic conventions. Discussing his work during one of our recurrent conversations, Jhon underscored how, in choosing to portray Jesus overlooking Ambon Bay rather than Jerusalem, he had used his "imagination." He also drew my attention to how Jesus not only overlooks Ambon but does so from the vantage of Karpan or Karang Panjang, a location above the city that is celebrated by its inhabitants as offering the best view of 
Ambon and that was often featured on the odd tourist brochure put out by the city's Department of Education and Culture before the war (Figure 11). The same view crops up in a colonial album of photomechanical scenes from around the archipelago, evidencing its framing already under the Dutch. On another occasion, during a tour of several days in which Jhon took me to visit churches and other locations around the city to see his work, we stopped at a small church that, with the madrasah next to it, served the religiously mixed population of the hospital on the grounds on which it stood. A large Christ painted behind the altar clasped a red heart to his chest in a scene that Jhon identified as the ascension, while a series of four paintings ran along the wall under the church windows. These, he said, depicted "creation" as a luxuriant green landscape, followed by the "birth" of Christ, "crucifixion," and "death" or, more precisely, resurrection showing a small illuminated Christ surfacing at the center of a circle of women in a cave-like enclosure. Except for the crucifixion, Jhon assured me, all the paintings were based on "models." When I remarked that the Christ with the heart struck me as Catholic, Jhon agreed but then quickly qualified any possible sense of emerging difference among diverse Christianities by insisting that "the objective is the same," 30 an ecumenical discourse that I take up in Chapter 4. Still, it is safe to assume that the model for the Christ with the sacred heart was not taken from the Protestant print repertoire. Instead, it evidences the tendency to bricolage that, along with loyalty to the canon and the desire to bring Christ close, also informed the changing iconography of Ambon's canonical pictures.

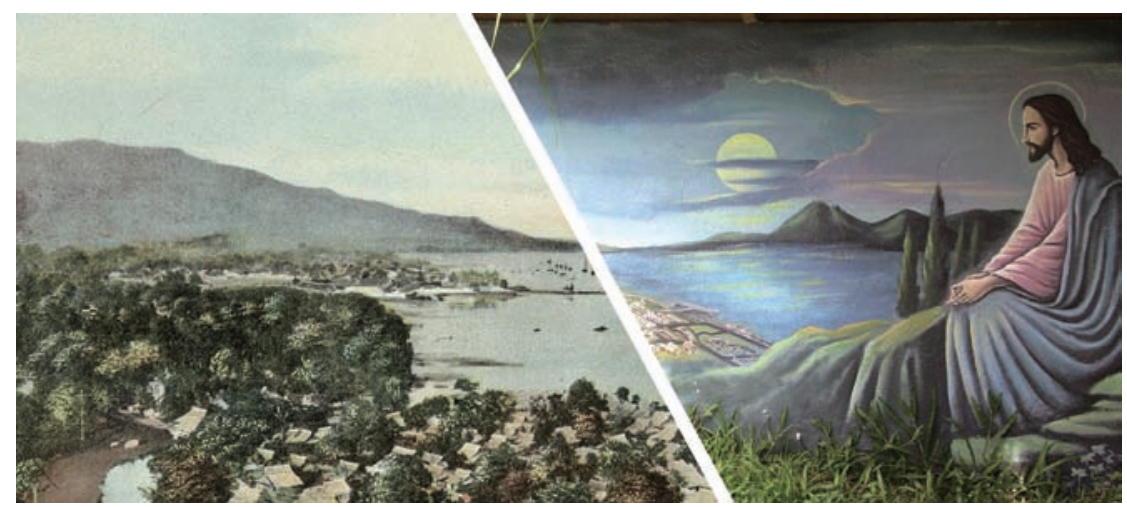

Figure 11. A composite image of a photomechanical picture of Amboina (left), the name of Ambon City under the Dutch colonizers, and a painted mural of Christ overlooking Ambon Bay from the same location (right). The photomechanical image originates from an album of scenic views of the Netherlands East Indies from the 1930 os or 1940 s. Reproduced by permission of the University of Cambridge Museum of Archaeology \& Anthropology (BA5/4/1). Mural painting by Jhon Yesayas, Ambon, 2005. Photo by the author. 
If in overt statements almost all of the painters emphasized their adherence to the Christian iconographic canon, in practice they creatively remediated and reimagined it in startling ways. Even as they departed from the reproduction of time-worn visual models, copying predominated as the point of departure in the artistic practice of the handful of men - with one notable exception-who painted Jesus Christ in the streets, behind church altars, and in private homes during and after the war. Given the restorative impulse that drove the Protestants' pictorial turn, such upholding of tradition is to be expected. However, due to the enormous pressure that the conflict exerted on the canon and what must also have been the sense of a diminishing correspondence between the print repertoire and the circumstances of war, all of Ambon's painters also, whether explicitly or not, relied on their "imagination," finding inspiration in the myriad materials around them to alter, elaborate on, and deploy the canon in unprecedented ways. Given how much the iconographic canon was rooted in European depictions of Christ and biblical scenes, the crisis of faith in the city may have summoned forth an awareness of the lack of correspondence already there-namely, between the colonially derived images and Ambon's Christian Protestant world. Continuing the focus of this chapter on Christ at large, specifically in Ambon's streets, I leave my introduction of the painters to the following chapter and turn now to the young men who supported the street pictures.

\section{Guardians of the Neighborhood}

In his fascinating analysis of the long history of guardhouses (I. gardu), "visible at almost every junction in major cities" in today's Indonesia, Abidin Kusno describes a photograph of pemuda, or male youth, from the Indonesian revolution waged against Dutch colonizers-young men who might have belonged to either the Indonesian National Army or unofficial militias but whose stylistic formation (in the photo at least) recalls the image of security guards standing at guardhouses in more contemporary times. ${ }^{31}$ But the scene is especially worth citing for the powerful ways the image resonates with the young men grouped across the city at the edge of their neighborhoods in postwar Ambon:

It was an image Indonesians would expect to confront as they approached the entrance to a guarded neighborhood. These youth represent the city (in ruins) behind them. They consider the city as being under their guard and see themselves as its protectors, as well as the destroyers of things associated with the enemy. Patrolling in selfstyled uniforms, they considered themselves to be the vanguard of the 
newly liberated world of the Indonesian masses (the rakyat). They took the urban space as a gigantic canvas on which they inscribed writing, slogans, and flags associated with this new time and new identity. They saw themselves as the embodiment of order and security, even though many of them participated in political violence and acts of destruction. ${ }^{32}$

Importantly, this passage captures not only the longue durée of such loci and the young men with whom they are identified but also the masculine style and sense of threat that the men equally embody. Dieter Bartels, an anthropologist who has worked for many years in Ambon, observes how the more open atmosphere resulting from Reformasi, along with the unrest of the city's conflict, offered such young men "an opportunity to express their freedom from authority through acts of violence." ${ }^{33} \mathrm{He}$ also writes of "Western-style gangs" that at times fought each other in some parts of the city before the war, as well as how these gangs morphed during the violence "into freedom fighters defending their neighborhoods against outside attacks and invading those of their enemies to burn them down." ${ }^{34}$ Some of the motorbikers recalled how in wartime men would pose before the Christian billboards and murals to be photographed, weapons in hand, before setting off to battle. A few others showed me their scars; one man, identified by another as "a victim" as he whirled his bike around to join us at the stand, rolled up his T-shirt to show me the ugly dark scar across his chest. Still others had tattoos, including the Star of David, a key symbol among Christians during the war. For the most part though, except for recurrent complaints about the Christians' makeshift weapons or statements about how the Muslims slaughtered them, the men avoided any reference to the violence. When they did remember the war, it was most often to compare the amount a biker could earn then with the much more meager take they could expect today.

When I inquired about the existence of biker associations, motorbike stand or group names, or neighborhood gangs, the men commonly reeled off the names of loud musical groups with which they or other motorbikers identified. For example, the response at one stand was the Sex Pistols, the name of the all-male disco group that some of the men had formed in order to participate in dance competitions. Not surprisingly, the wall behind the platform on which the bikers sat between rides and during lulls in business bore the logo of the band enclosed in a ring of dripping blood that made it resemble a bullet hole-"because we live and die for this," one of the bikers explained when I wondered about the design (Figure 12). "For us," another continued, as a number of the men crowded around to listen in on our conversation, the logo or, perhaps more accurately, brand "is the same as Coca-Cola-always Coca-Cola, 

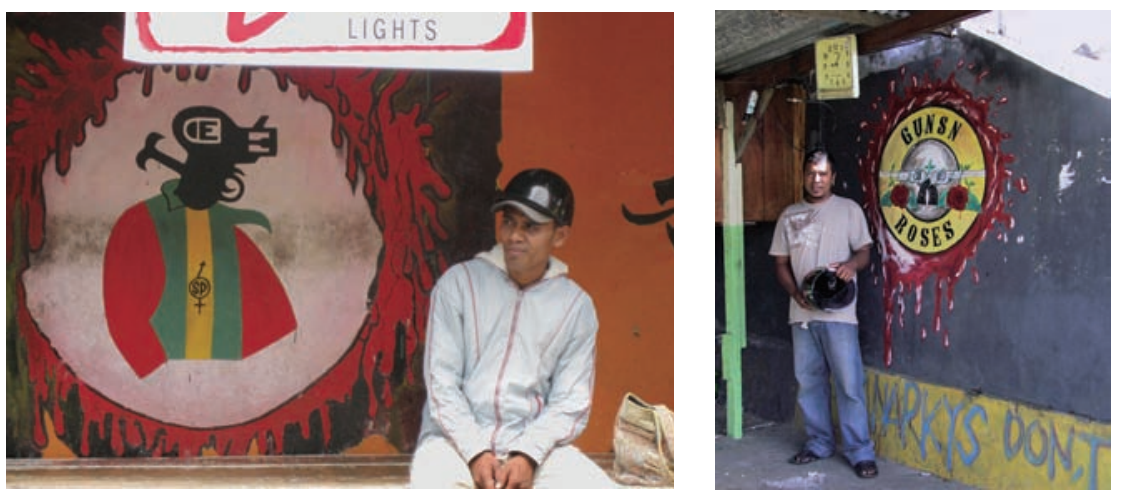

Figure 12. Sex Pistols and Guns N' Roses logos at a Christian motorbike-taxi stand (left) and a Muslim one (right), Ambon and Ternate, 2006. Photos by the author.

always Sex Pistols." 35 Around the city, many such biker "brands" were similarly adopted and, at times, adapted from the emblems of musical groups.

Not only the young Christian men whom I spent time with in Ambon in the mid-20oos but also those I met in April 2006 in North Malukan Ternate and in 2008 both there and in neighboring Tidore-where the populations are predominantly Muslim - embellished their stands with designs taken from the CDs and DVDs of bands like Guns N' Roses, Limp Bizkit, Linkin Park, and, of course, the Sex Pistols. Some names were apparently holdovers from earlier times, such as the Gipsy Kings, a band popular in the 1980s, "during the time of our fathers," one of Ambon's bikers remarked. Faces like those of Che Guevara or the Indonesian cult singer Iwan Fals, along with slogans like "Punk" and "Rebel," also moved indiscriminately across Indonesia's many religions and regions and settled into the rich stratigraphy of these sites (Figure 13). ${ }^{36}$ Besides such consumer- and youth-based sources, a study of these sites' stratigraphy would reveal other group markers as well, especially, as I noted earlier, those of political parties and soccer teams. Apart from the display of consumer culture and myriad emblems, the Christian billboards-whether freestanding or adjacent to murals covered with Christian scenes-often emerged in the same kind of location, along the city's main thoroughfares or at crossroads facing onto major streets, as commercial advertisements, if, indeed, they had not been painted over these. This, for instance, was said to be the case of the alleged first Christ portrait in the city that overlay a former Sampoerna cigarette advertisement.

Beyond their explicit wartime and postwar identification with Christianity, Ambon's men and their bike stands form part of a wider masculine youth 
culture that draws inspiration, emblems, and sources of style from a common repertoire that is seen across Indonesia. In 2006 and 2008 in the North Malukan sultanates of Ternate and Tidore, I even came across a few Muslim power murals, similarly connected to male neighborhood stands, although these were few and far between. ${ }^{37}$ Unlike the Christian murals, I only saw one in North Malukan Ternate, although there was also a billboard showing Saddam Hussein on a stallion chasing a tiny, sweating George Bush. On the small neighboring island of Tidore, there was another Muslim power mural, but I saw none in Ambon or elsewhere in Central Maluku. Although only the Ternate mural bears the "Moslem Power" slogan, both form stunning portrait galleries featuring such historical and political male heavyweights as Indonesia's first president, Sukarno; the eighteenth-century anticolonial Malukan hero Nuku; long-time opposition singer Iwan Fals; Muammar al-Qaddafi; and Osama bin Laden (Figure 14). Like the Christian walls, they served on occasion as openair photographic studios. In Ternate, I was shown photographs of groups of young men as well as married couples posing in their new Ramadan clothing in front of the power mural there. When I began to photograph the Tidoran mural, a man repairing the gutter next to the wall spontaneously jumped in front of my camera, raising his thumb in approval of the huge portrait of Saddam Hussein in front of which he stood. Similar to the Christians, the Muslims took their examples from print media, in this case, hard-line Islamist magazines like Sabili or more traditional print lineups of Muslim religious leaders like those I saw hanging in Ternatan homes along with larger images of the holy city, Mecca. Importantly, the men who did the mural were themselves not Islamist in orientation. Both the Muslim and Christian propaganda at these locations and their designation as motorbike-taxi stands dates from the war when the bikes flourished as substitutes for public minibuses and cars due to their safer and more malleable mobility. Nonetheless, the major difference between the Muslim and Christian murals is that while the former proclaim a long history of Muslim greatness, if somewhat defensively in the aftermath of war (see also Chapter 5), the latter claim in the first place a novel visibility as they envision a more proximate connection to the Christian God.

It is worth pointing out that, in all of my conversations with the bikers of different stands around Ambon, only infrequently was any mention made of the city's most famous - or infamous - gang. Dating from the war and hailing from the Christian neighborhood of Kudamati, the group Coker, short for Cowok Keren or the "cool men," were led by Agus Wattimena, a man widely recognized as a preman or thug. Whatever wartime violence any of the bikers had been involved in, none of these self-assigned neighborhood guardians, as far as I could tell, formed a gang along the lines of Coker that lived and 

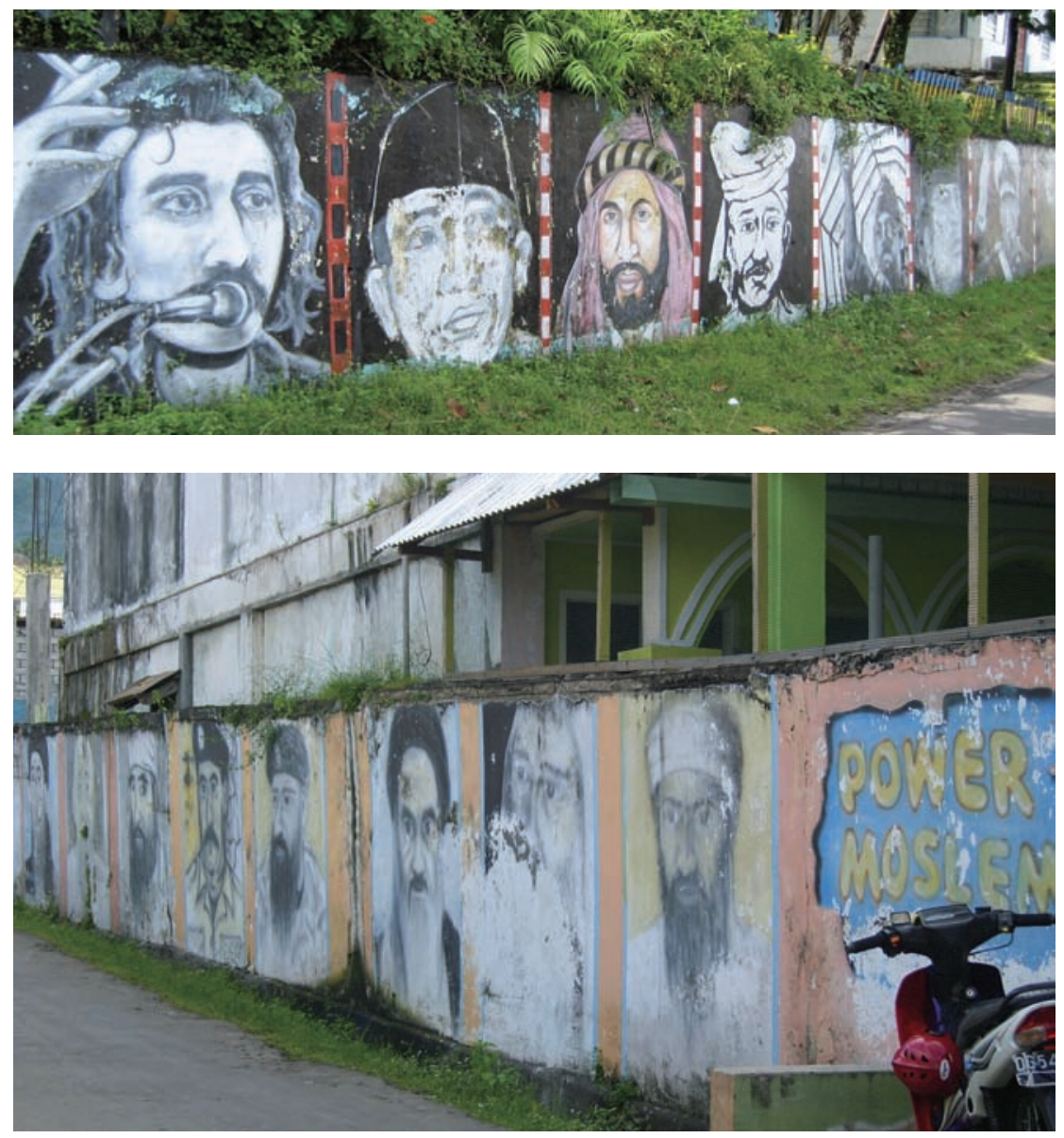

Figure 13 and Figure 14. Muslim power murals in North Maluku (top), Tidore, 2008. Photo by the author. The Ternate "Moslem Power" mural painting (bottom) was painted and photographed by Aki Saleh, reproduced with permission.

reproduced itself through violence and extortion. Speaking of the gang, a Christian woman who I will call Lusi used the phrase "Christian pemuda," to refer to its members, evoking the revolutionary youth described above, but adding a local twist that merged the storied heroes of the Indonesian nation with Ambon's own homegrown Christian freedom fighters. But Lusi's praise for these pemuda was ambivalent, since members of the gang would apparently betray their fellow Christians for a fee, or so she claimed, by, for instance, setting their homes on fire. This explains her other name for the men-"Judas's kids," the term used for duplicitous Christians during the conflict. ${ }^{38}$ 
In contrast to the gang, the men I came to know in the mid-20oos-including as a frequent motorbike-taxi passenger-formed loose motorbike-taxi collectives, the members of which identified strongly with their neighborhood and stand, including its corresponding signs - the "brands" of their favorite musical groups; those of preferred political parties, notably in the early zooos, Megawati Sukarnoputri's PDI-P political party with its black-on-red water buffalo logo among the Christians; and the especially charged Christian billboards and murals. Not all of the men associated with a given bike stand had necessarily grown up together, given the many displacements of the war. But they were closely knit by ties of loyalty, friendship, shared history, and their common identity as both Christians and young men. Although by no means systematic across the biker groups, some collected fees to cover the costs of treatment should any member be involved in an accident or fall ill. Collectively, they pooled the resources to pay for the street paintings-supplying the painters with paint, brushes, and other materials, including the usual, so-called cigarette price, a gloss for the cigarettes and snacks given to the painter while he worked. They also took charge of the upkeep of the murals and their immediate surroundings, especially in anticipation of Christian holidays, when they would decorate the sites festively. Members of the neighborhood often chipped in, especially around Christmas.

Although the general function of these locations was clear to me, it proved impossible to obtain detailed information about their history during the war. This may have had something to do with my gender and age at the time of fieldwork but also perhaps because for most of the men, there was not a great deal to say: as in ordinary times, the defensive function of the neighborhood guardhouses was obvious; in wartime this had simply been expanded and made more explicit. But, once in a while, I sensed reticence on the part of some men who seemed reluctant to recall war's troubling episodes, as well as things that they may have felt were better left unsaid, if not forgotten.

But if these men, like the Indonesian revolutionaries before them but also youth the world over, took the city as their canvas as Abidin Kusno describes, equally evident in Ambon was the diffuse sense of threat that he also recordsbut also, by extension, neighborhood security-that emanated from the men and their stands. Recall that, in many cases, the combination of command and communication posts that were established during the war occupied the same strategic locations at the borders of urban neighborhoods as the motorbike-taxi stands do today. These were especially potent sites at the time, as we saw in Chapter 1-places where prayers were said and trumpets blown, where processions of Christian men and women set off holding images of Jesus Christ high above the crowd, and where the alarm sounded, rousing the neighborhood, in 
the case of an attack. Tellingly in the Southeast Malukan islands of Aru, the Indonesian state required villages to construct the guardhouses that, at this eastern end of the archipelago, had never been seen before, as part of the preparations for the 1987 national elections. As I came to understand, the need for such defensive structures was meant to conjure the possibility of an unseen enemy who might emerge at any time to challenge the Indonesian state. According to the same logic, Aruese men were forced to train with mock guns they were told to carve from wood in case "something happened." ${ }^{39}$ I mention this example to underscore the enormous strategic role linked to the ubiquitous guardhouses-whether in everyday circumstances, elections under Suharto, or wartime. But also to bring out their long-standing, intimate connection with forms of state control-connections that were enhanced during the Japanese occupation of Indonesia during World War II (1942-1945) through the system of neighborhood organization that the occupiers imposed to monitor and control the population and that was consolidated and expanded under Suharto. ${ }^{40}$ To give just one example of their defensive function in ordinary times, a Catholic priest based at a church across the road from one of the biker stands, a man who I knew from my time in Aru, told me of an incident in which the electricity in the neighborhood had gone out and a woman employed in his home called out for help when she saw someone spying on her through a window. Within minutes, the priest recalled, along with his own surprise at the time, forty motorbikers had surrounded his house. When they caught the offender, the bikers "roughed him up a bit," but the priest insisted they turn the man over to him since he had been caught trespassing on church grounds. ${ }^{41}$ Socially, symbolically, but also defensively standing in for their neighborhoods, the guardhouses, in other words, are places where multiple social and strategic needs are met, today as in the past.

Due to their predominantly young age, gender, and, commonly, unmarried status, the men who hang out at these spots in front of their neighborhoods tend to inhabit a place at authority's edge. Their creative activities, notably the Christian pictures, are not sanctioned by the local churches, who tend to regard them with ambivalence, often commending the images for how they showcase Christianity but voicing doubts about the religiosity of the young men who make the pictures or cynicism regarding the un-Christian behavior that they assume takes place around them. Indeed, it is these young men who the painter Jhon had in mind when he described his street art to me as pictorial khutbah or sermons, and he claimed some success. Sitting across from Christ's face, these men are less inclined to drink or fool around with women, or so Jhon said. ${ }^{42}$ In casting his paintings in the role of Pentecostal witnessing, the painter also betrayed the influence of the charismatic church he had begun to attend 
at the time even as he continued to join services at the GPM, intimating a shift in which he was hardly alone (see Chapter 4).

As elsewhere, such men are the recurrent object of suspicion and surveillance and, where possible, are mobilized to political ends in decentralized Indonesia's continual campaigns and elections. For instance, around election time it is not uncommon to see small television monitors appear in motorbike stands in addition to the even more common bright new T-shirts on the motorbikers. ${ }^{43}$ Importantly, these groups are a phenomenon of orphaned landscapes, surfacing in wartime and afterward, when the guardhouses and their occupants became exemplary of the grassroots emergence of forms of authority and regulation, the enhancement of defensive protection, and, in Ambon, a religious definition of these processes. In this respect, it is important to recall that on the other side of the city, young Muslim men grouped at motorbike stands mirrored the loose neighborhood gangs of the Christians. As memories of the war faded, some of these groups collaborated as the Christians manned the Muslim stands during Muslim holidays, providing transportation for Muslim passengers and vice versa, as I discovered in 2017.

But in war's immediate aftermath, many more men than women were left without sources of employment. ${ }^{44} \mathrm{Un}(\mathrm{der})$ employment in the city especially affected its young people, comprising close to 60 percent of the urban population. There is also disturbing evidence of quite widespread domestic violence, as well as violence in schools following the war. ${ }^{45}$ For many of the young motorbike-taxi drivers who are neither married nor in schools, these specific types of violence may not be directly relevant. But they do speak to the war's widespread trauma and other effects and to its ongoing consequences in the postwar city-including those that resulted from the devastation and scrambling of neighborhoods due to the redrawing and hardening of territorial boundaries and internal displacements, the memories of violence and the psychological and psychosocial damage resulting from the constant threat of violence, the loss of family and friends, the interruption or termination of school and employment, the destruction of futures and hope. There were, of course, differences among the men in this regard. In the mid-200os, some of the older members of the biker groups were those who, in war's wake, were among Ambon's most adrift-their past clouded and often violent, their present precarious, and their future up for grabs. Others were more settled-younger men for whom motorbike-taxi driving was a source of income and a privileged component of masculine style, students aiming to support their studies, or the odd civil servant moonlighting to supplement his salary. ${ }^{46}$ Among the differences were also those of class, since before the war a civil servant, and especially a Christian one, would not have been easily caught driving a pedicab or 
motorbike. Indeed, one of the most common ways that middle-class Christians had of summarizing the decline in their social position was to point out that after the war, even Christians drove pedicabs, considered the lowliest of occupations.

\section{Streetwise Masculinity}

War and the city's postwar streets elicited masculine performances in which the male body figured centrally. It is possible that the precarity of postwar existence, more aggravated in many respects for men, may have further provoked the display of male power, whether in the form of domestic or other physical violence or through more sublimated forms like the Christian street art. Whatever the case, style among the city's young men is an ongoing preoccupation in which the motorbike assumes special importance as a crucial component of masculine performance. Demonstrative strutting and cruising has long been a feature of Ambon's streets, where men critically assess each other's performances. ${ }^{47}$ Equally important is the creative work that goes into embellishing the motorbike as an accessory and instrument of masculine display and, collectively, the painting and decoration of the motorbike stand. ${ }^{48}$ These different elements of style, male bravado, and group identity come together in stunning photographs of men performing stunts on their motorbikes in front of the Christ murals, as I discuss below.

If style generally is something to be put on show, then such style was performed with a vengeance during and after Ambon's war. A Protestant minister spoke to me of the first Pattimura Day celebration held in the city in mid-May 2005 to commemorate the resistance to Dutch colonial rule on the part of the nineteenth-century Christian hero and his followers. ${ }^{49}$ Part of the ceremony includes a performance of the cakalele war dance by Christian men dressed in ancestral wartime attire upon their arrival to Ambon City from Saparua Island. If always impressive, the first postwar performance took place in that part of the city where the conflict began and in other ways, too, was especially uncanny. Following so closely upon the war's conclusion, the spectacle of the bare-chested men brandishing many of the same machetes they had only recently used in combat could not but evoke the city's immediate past and, what is more, be infused by some of the same passions and energies that drove the widespread violence, or so the minister said. With a hint of amusement, he added how it was obvious that a number of the men had prepared themselves for the public performance through some extra bodybuilding. Two years earlier in 2003, as I sat in front of my hotel enjoying the relative cool of the evening, I witnessed countless practice sessions that filled the wide, tree-lined Pattimura Avenue leading up to the city's first national Independence Day celebration 
since the war. Late into the night, groups of twenty to thirty young men-but also some women-marched up and down the avenue in military style to the tune of a harmonica or a whistle blown to keep them in line. Variations on the style included "beautiful marching," which replaces the tight discipline of the military version with graceful, flowing movements, or another in which the military march alternates with short bouts of break dancing. Eager for some entertainment after the difficult years of conflict, people at the time commented enthusiastically about the impressive number of groups that had signed up for the Independence Day parade and how fabulous they would look in their different, color-coordinated clothing.

Cocky, streetwise, and displaying a decidedly Christian sense of style, Ambon's young men were key customers for the booming wartime market in Christian-themed T-shirts and the crosses that grew to immense sizes around their necks like some sacred Malukan bling. Music, stickers, and signs distinguishing minibuses destined for different parts of the city became demonstrably religious in nature, echoing in a different scale and register the aggressively spectacular Christian billboards and murals. Not surprisingly, the street pictures lent themselves to masculine performances, resulting in striking juxtapositions of canonical Christianity and monumentalized male bravado. While taking photographs of a motorbike-taxi stand one day, a few of the bikers offered to show me what they called their own dokumentasi, or photo collection documenting the "before" and "after" of their decorated motorbike stand and adjacent wall. ${ }^{50}$ Some of the photographs showed these sites at different stages of completion; in others, the men gathered proudly around the partially done or finished wall. Among the stacks and small plastic albums provided by stores when they return printed photographs were scenes of group activities that captured male camaraderie and fun on camera-a motorbike excursion and boat trip to Seram during durian season, men striking poses next to their bikes or performing stunts at motorbike rallies. Taken over a period of time, the photographs recorded the shifting stylistic, political, and religious identifications of the group and the creativity displayed in their articulation.

But the most striking in the bikers' self-documentation were several photographs that showed young men performing motorbike stunts in front of Christian billboards and murals. In these pictures, male bodies merge with the Christian scenes behind them, as in one remarkable image in which the erect bike, supported by its owner dressed in his Christmas best, aligns perfectly with the crucified Christ behind it. In these carefully preserved photographs, the double import of backdrops in the construction of Christian identity and youthful masculinity alike comes to the fore: bikes, bling, and backdrops work together as prostheses of male bodies in public space, as the props of male performances, or even, following a more expansive definition, as a bodily 
adornment of the pictured body, fashioning the subject within..$^{51}$ This is nowhere more evident than when the bike aligns with the Christ backdrop in a dramatic expression of male motorbiker style and a masculine assertion of public Christianity. As a photograph, specifically, the picture offers a more intimate take on who this man and others like him "want to be when they pose before the camera." ${ }^{52}$ In doing so, this remarkable shot folds into its frame but also into each other the seductive bravado of youthful male bluster and the power of pictures-including that of the global print Christianity from which the model for the billboard derives; the imaginative, theatrical space offered by the backdrop itself; ${ }^{53}$ the glossy appeal of advertising that suffuses the gigantic airbrushed Christ; the performative force of being who you want to be before the camera, as well as, explicitly here, out in public space and poised for widespread consumption; the material presence of the monumental, in-your-face Christian street picture itself.

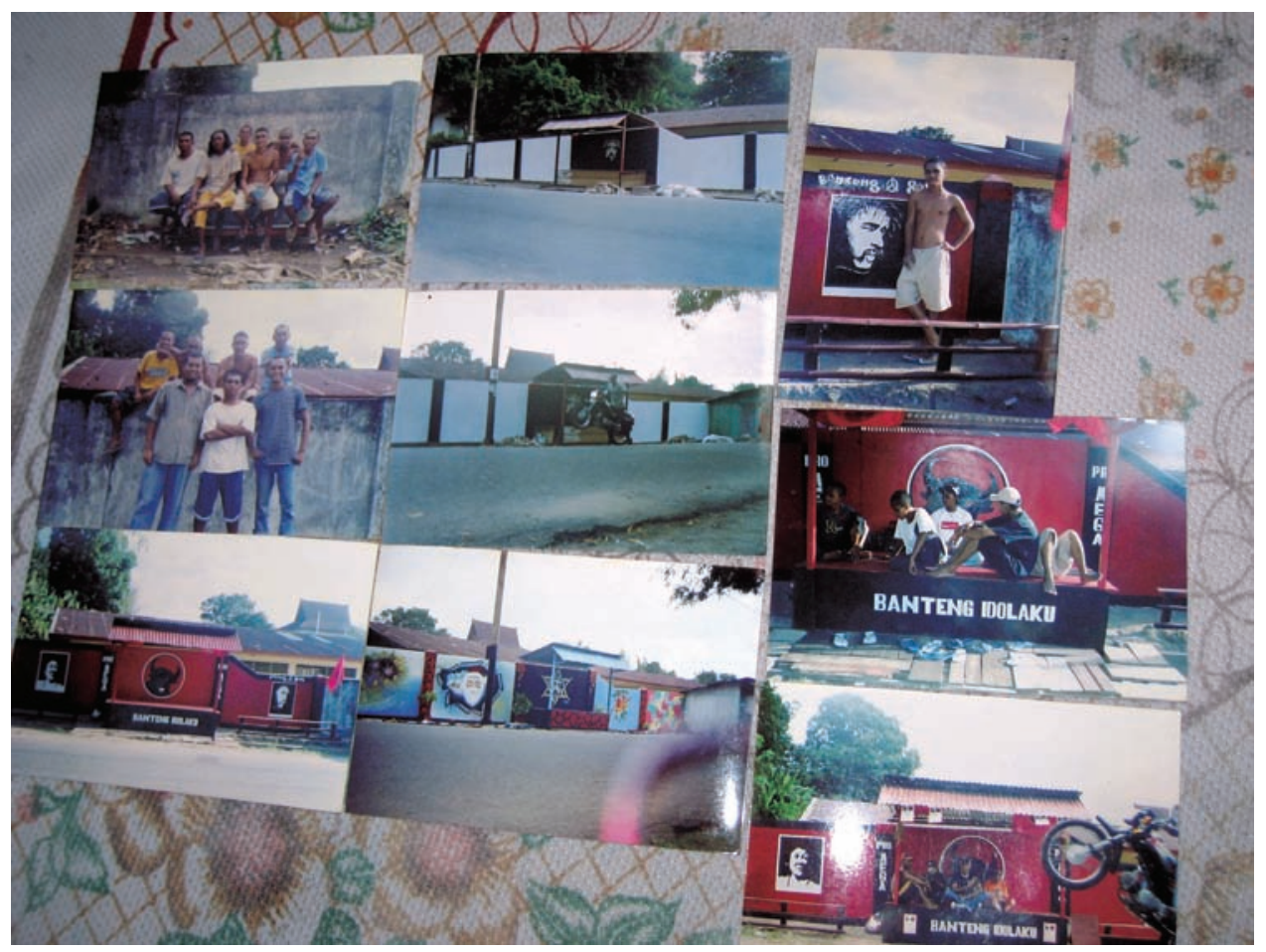

Figure 15. A photo album showing the range of sources that different Christian motorbike-taxi groups draw on, from the logos of political parties and portraits of political leaders, Christian print media, and the Israeli flag, to Dutch Christmas cards, T-shirts, and musical groups. Notable is the importance given by some groups to documenting the creative embellishment of their stands and the ubiquitous presence of the motorbike. Ambon 2003, 2005, and 2006. Photos by the author and by motorbikers. 

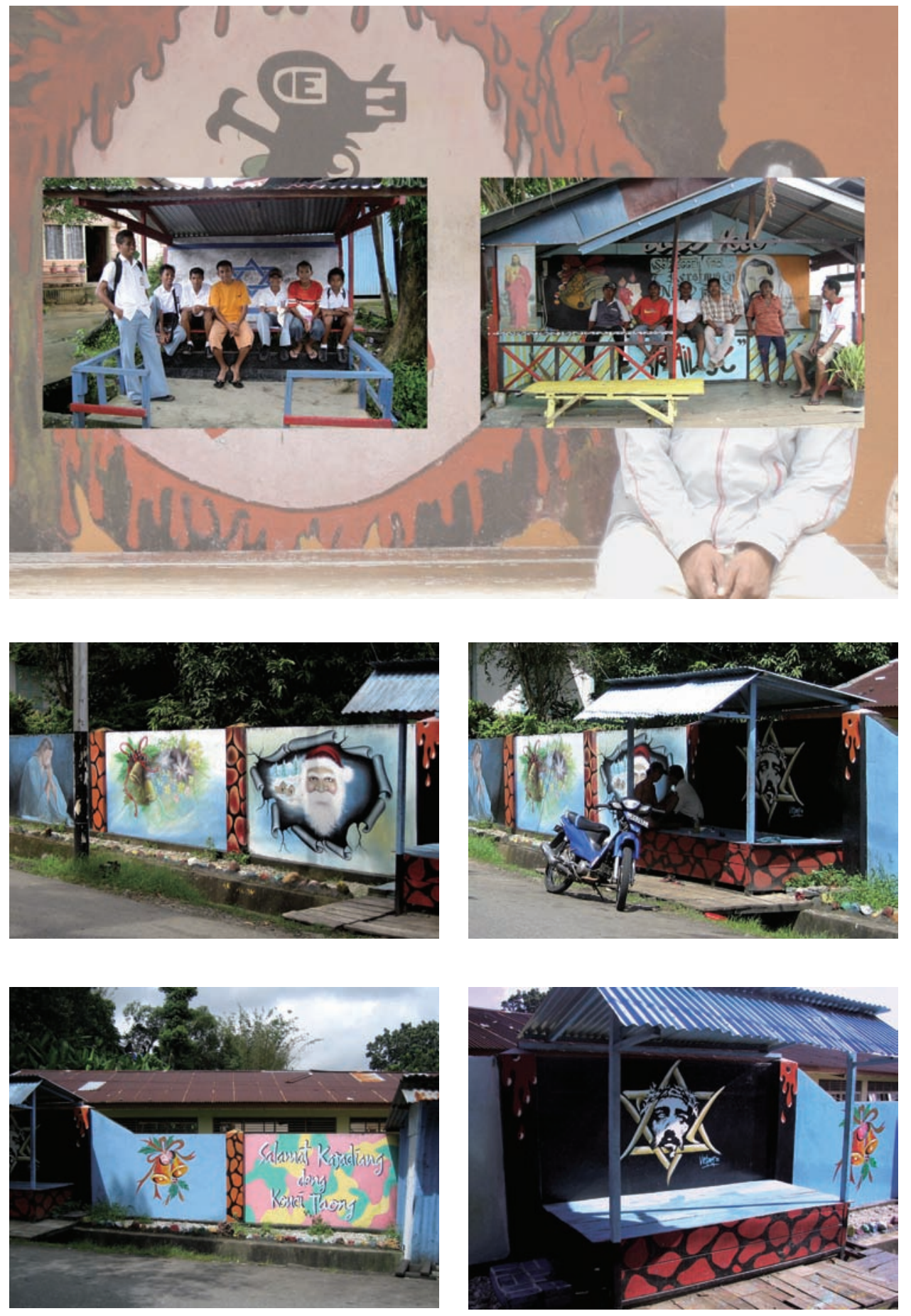

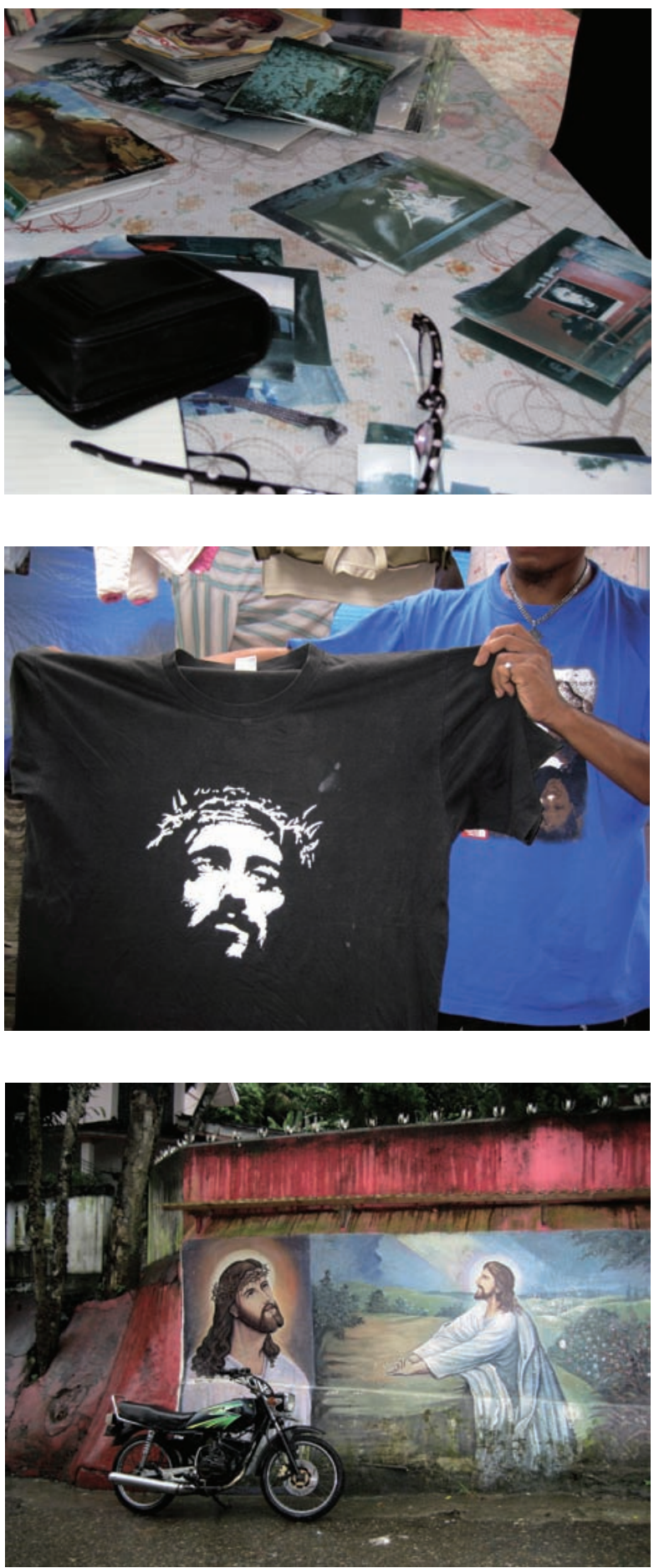

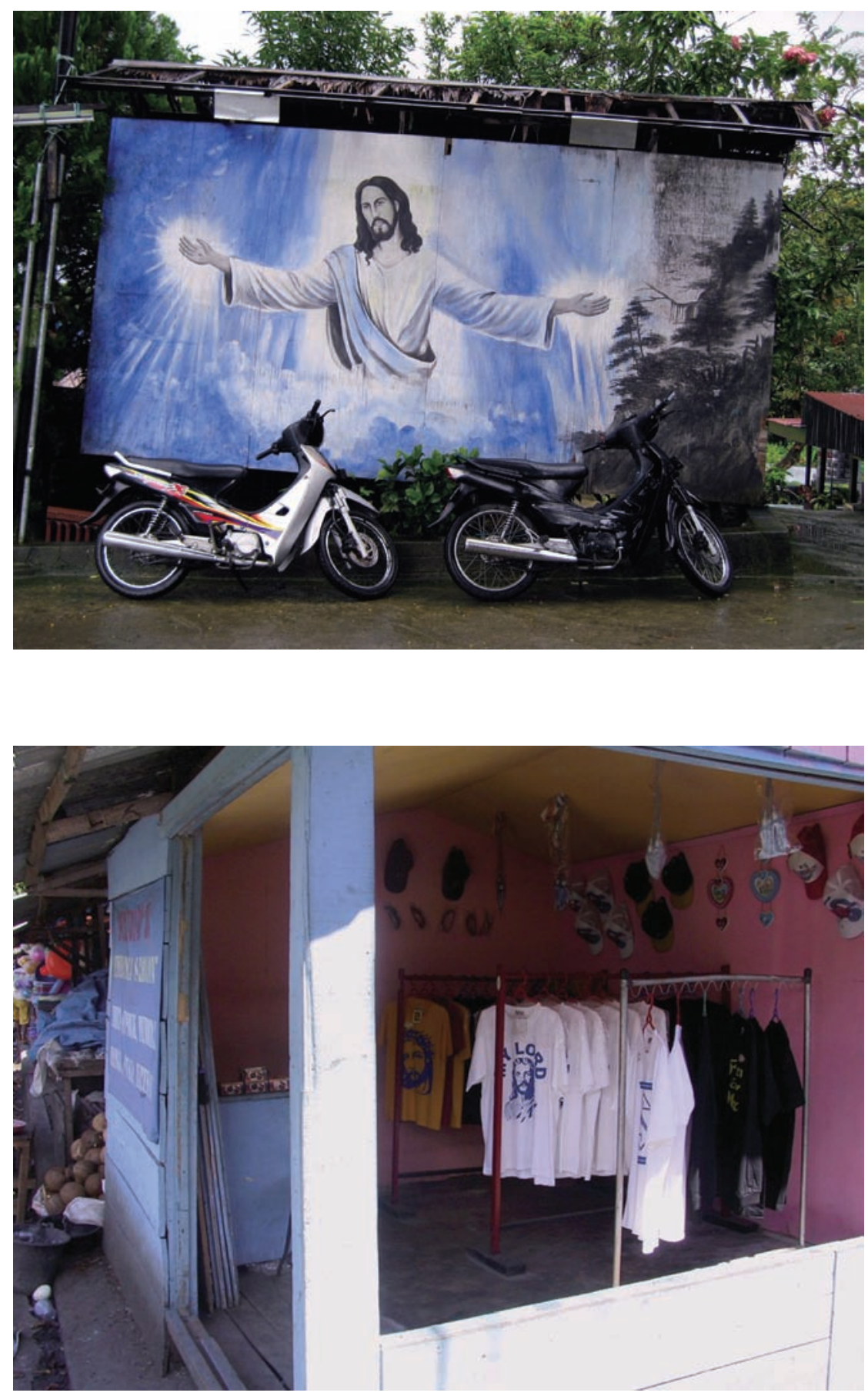

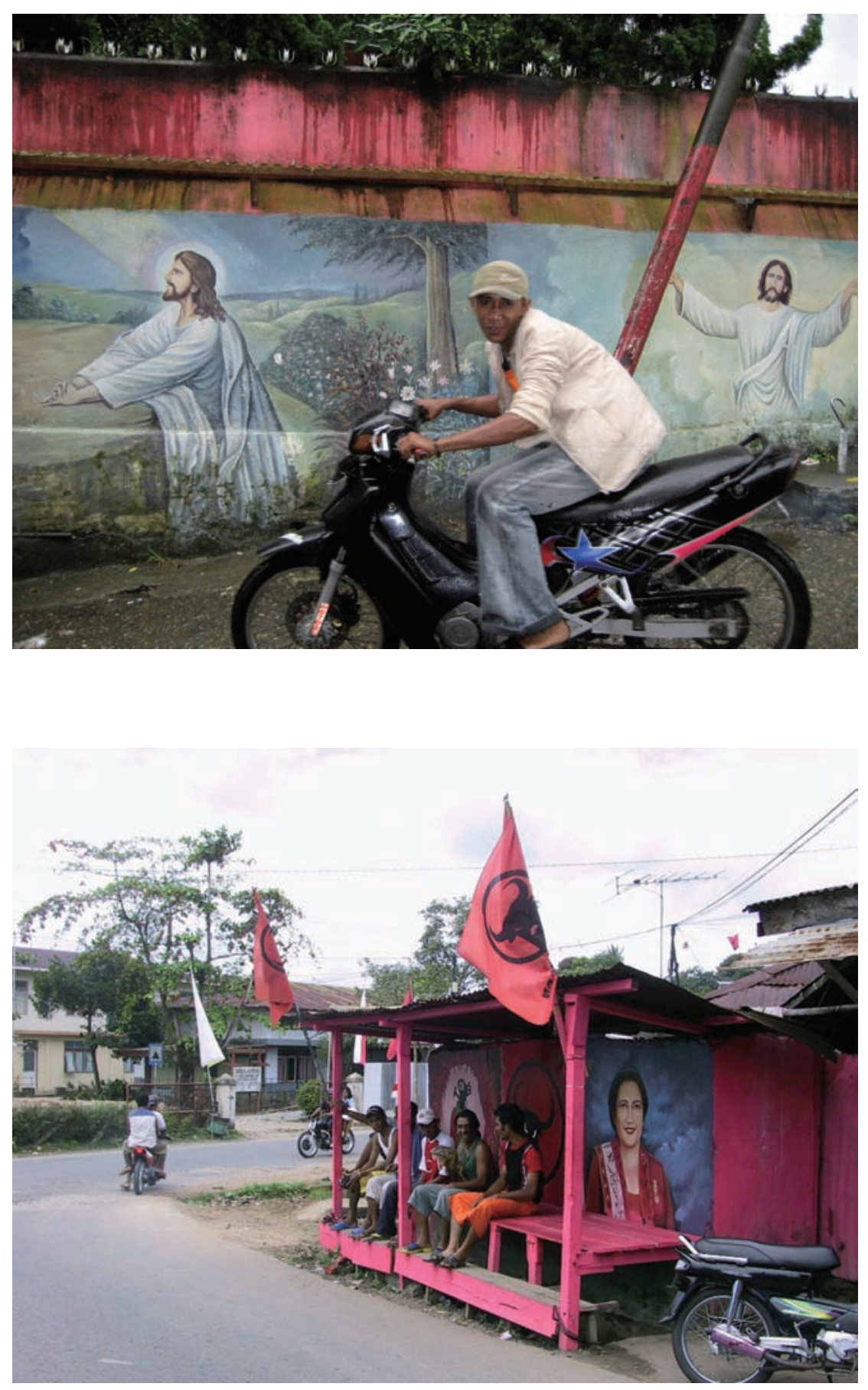


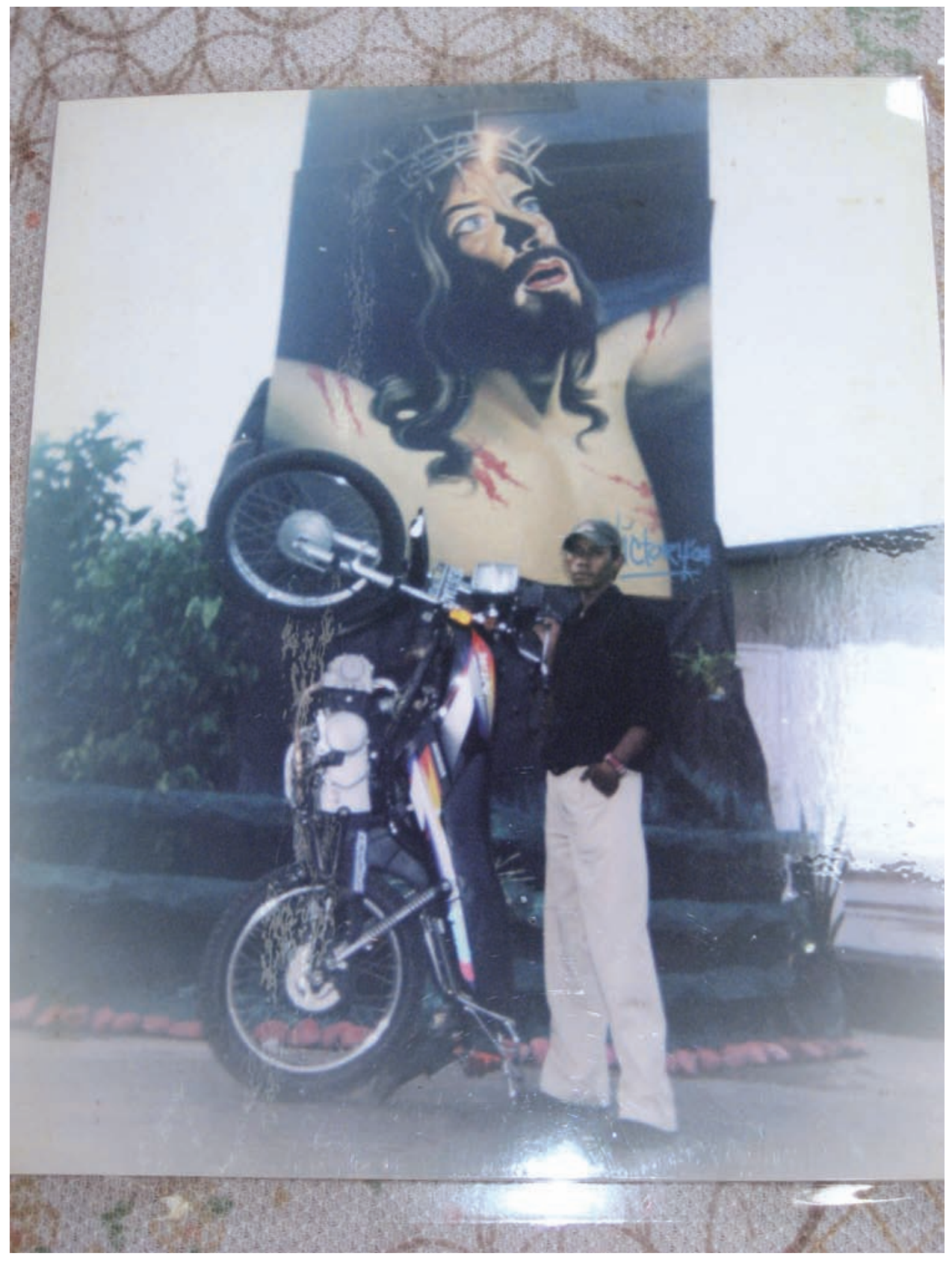




\section{This Face Wants you}

This is what the Christian billboards and murals say to the pedestrians, motorcycles, cars, and minibuses that pass them by. It is also what they say to the young men who, in Christian neighborhoods around the city, hang out on the raised platforms facing the megapictures-passing their time, smoking cigarettes, gossiping, and reviewing passersby (especially young women) while awaiting motorbike-taxi customers. Looming over this terrain, Jesus's gigantic, glossy face with its adjacent murals simultaneously gates the community and brands it as decidedly Christian. In doing so, these pictures posit a direct relationship between the core symbols of the Ambonese Christian community and physical territory at the same time as they facilitate an identification between the martyred male Jesus and the young men who gather around his image and, in turn, through them, a connection to the wider community for which they stand. This, incidentally, is an identification fully enabled by the teachings of Protestant Christianity. In Chapter 3, I consider more closely the identificatory circuit that is established discursively and via the pictures between Jesus Christ and Christians, one based on an inherently visual idea-namely, that of man being created in the image and likeness of God. For the young men who sponsored and cared for the pictures, the significance of the connection between themselves and Jesus was, however, not circumscribed by the teachings of Christianity but centered also on his identity as a young man. Whether Christian or, for that matter, Muslim, Indonesia's neighborhood guardhouses have long been sites of masculine identity and expression. This explains why, besides men, only older women from the neighborhood might pause briefly with their parcels from the market in the bike stand before heading up the hill. But it also explains the concern on the part of the priest whose church is in full view of one of the biker stands that the large statue of the Virgin Mary planned for its pinnacle might offend its occupants (Figure 16). In my view, his observation had less to do with any explicit difference between Protestants and Catholics, something that was actually deemphasized during the war, than the more elevated position of the Virgin vis-à-vis the stand and its adjacent Christ murals. Recall, in this respect, Jhon's description of the billboard that stood in front of this motorbike stand during the war but was removed when its scaffolding rusted: "That is the one we made like an advertisement, so we raised it up high, higher than all the other images because of his being on high." Not only would the Catholic statue symbolically eclipse Protestantism's privileged position and superiority, but it would also install a markedly Catholic female figure looking down on the male sociality grouped around the bike stand. Not surprisingly, the adamant masculinity of these 


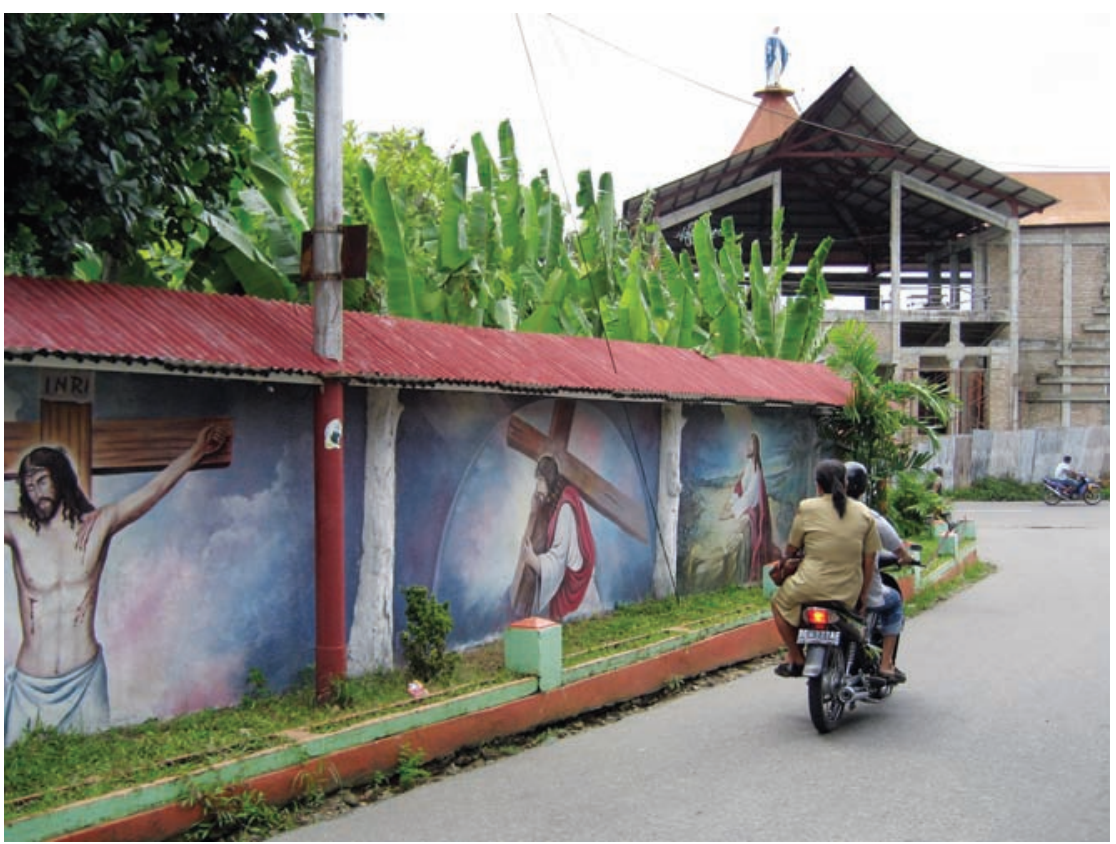

Figure 16. Statue of the Virgin Mary overlooking the mural painting of Christ across from a motorbike-taxi stand, Ambon, 2005. Photo by the author.

stands comes across in the iconography of the Protestant murals where the only women occasionally depicted serve as props to Christ, either as his mother Mary or the handful of women witnessing his resurrection.

Taken together, the territorial claims and Christian scenes built into and arising at these defensive neighborhood locations fed on and were energized by the symbolically charged, dense sociality that converges on the borders demarcating Ambon's Christian neighborhoods-increasingly anxiously and self-consciously-from the city and country around them. At these potent sites, highly territorial versions of community became articulated at the same time as the very idea of community in relation to territoriality became the site of creative exploration and experimentation-especially via the pictures thrown up on billboards and walls. Born out of conflict and an intimate part of the scene of war, the Christ at large in Ambon's postwar streets was, among other things, an emblem of violence where the difference between self-love and other-directed aggression was hard to discern. Seen in this light, the street art has much in common with the wartime graffiti that a journalist described as either self-referential or about the enemy-Israeli versus Egyptian territory, 
Muslim power or Muslim pigs. ${ }^{4}$ "We live and die for this," one biker explained, speaking of the musical group linked to his stand-and although he referred to the Sex Pistols, it might as well have been Jesus Christ. Invoked frequently by Christians lamenting their circumstances during the war, many claimed that "Christ was our only weapon," as they went on to recall the flimsy bows and arrows, makeshift rifles, home-brewed poisons, and occasional black magic with which they aimed to protect themselves. The Lion Alley wall showing Jesus holding a Sacred Heart encircled by thorns with flames shooting out of it looked to some like an exploding bomb encased in barbed wire (Figure 17). Such comments speak less to the skill-or lack of such-on the part of the particular artist involved than to how easily Christ and violence collaborated during the war. Recall, along these lines, how Jesus Christ's apparition often prefigured the onset of violence, or how some Christians-but allegedly, too, a handful of soldiers and several Muslims-saw him commanding the Christians in battle. Beyond these religious associations, bullet holes with bloody skin bent back to frame motorbike emblems or pistols in the place of heads on torsos have long been popular images at bike stands. Even if Christ on billboards and murals is depicted overlooking rather than immersed in violence-a crucial distinction-he remains close to and engaged with it. What his separation from war's all-encompassing terrifying terrain enables is seeing Christ as a comforting rather than a foreboding force.

If, during the war, Ambon's Christian pictures poetically, but also provocatively, publicized the question of territory in a city rent by violence, the practice of graffiti, often deployed in anticipation or in the aftermath of confrontation, served to advertise territorial conquests by inscribing the respective losses and gains of the enemies directly onto urban space. On either side, competing sound bites sprayed on city walls claimed territory for the self while defacing the opponent. Insults of Jesus or the Prophet Mohammad traded places with Stars of David, the names Israel and Mossad, or "Allahu akbar" in Arabic writing (Figure 18). All of these markings violently scratched onto the face of the city bore within them highly charged figures of territory: they staked claims to homes, public buildings, beaches, and stores, and to strategic loci in and around the city. ${ }^{55}$ They desecrated the ground only recently relinquished by the foe, registered the vicious back-and-forth of enmity and contestation, cordoned and enclaved the community. Charged with aggression and meant to insult and provoke the enemy, such markings were the material conduits of the affective intensities, emotional commitments, and circulation of energies that animated the work on appearance during the war, especially that which took place in the streets and was driven (largely) by men-those who defended and fought for their neighborhoods, who gated and branded them with Christian scenes, 

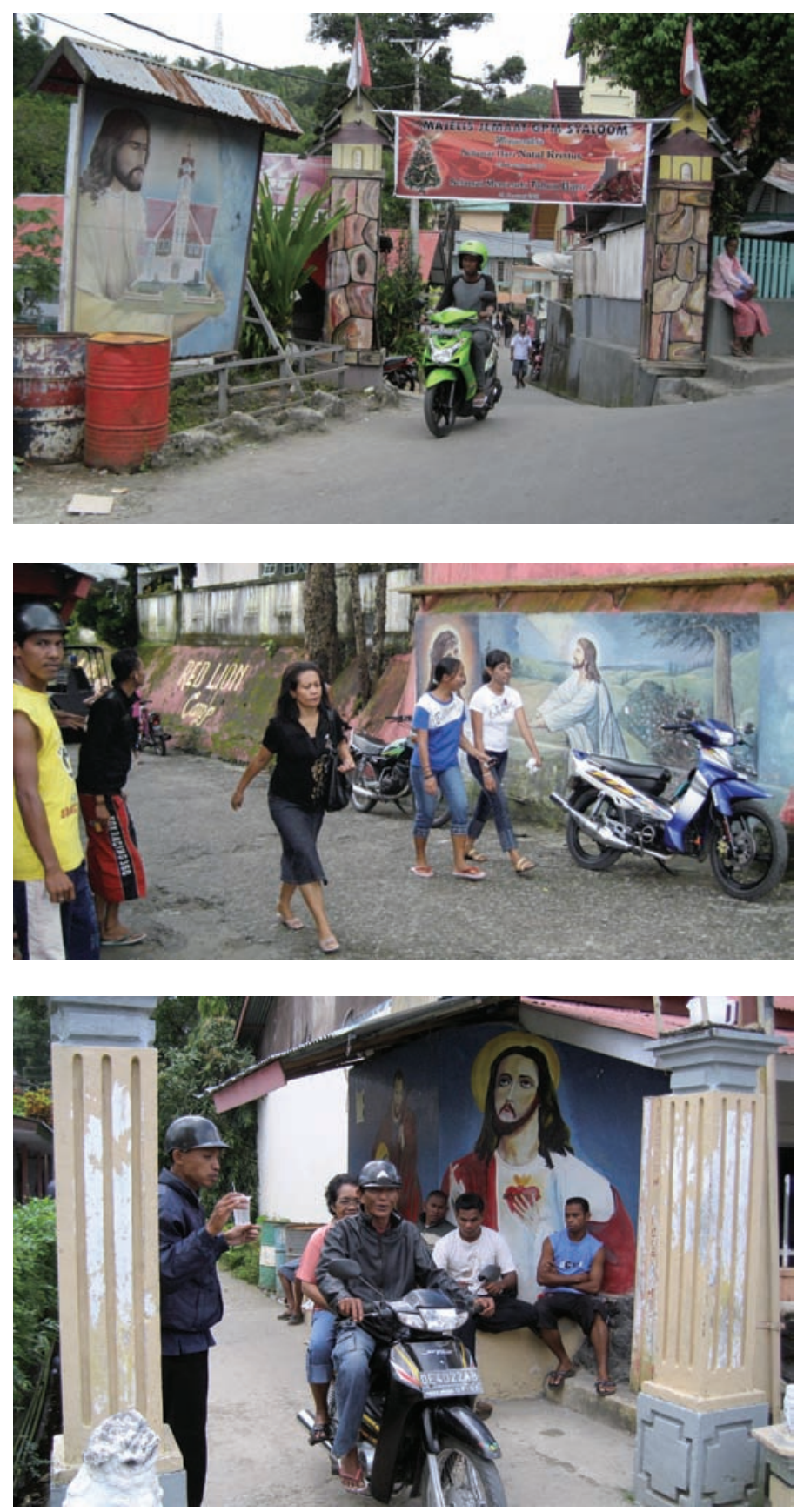

Figure 17. Christian neighborhood gateways, Ambon, 2005 and 2006. Photos by the author. 


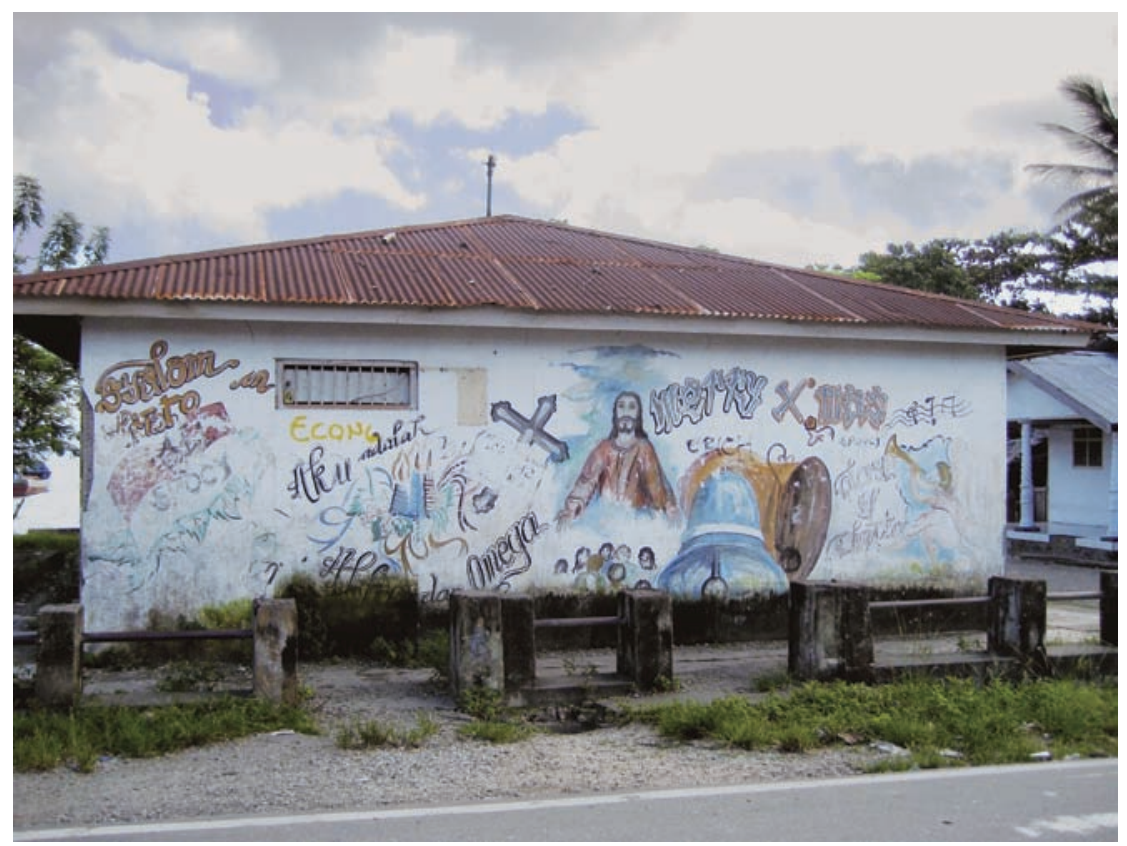

Figure 18. Wall with tags, graffiti, and a painted Christ and church bells that gives a sense of the diverse range to which such urban canvases are put. Soahuku town, Seram Island, 2005. Photo by the author.

who did stunts, posed, and photographed themselves in front of the Christ billboards and murals. It is worth recalling that, besides the Muslim enemy, another factor that must have energized the street art and fed its creative dynamism was the presence of multiple groups of such men around the city and the considerable competition among them, at no time more than in the weeks preceding Christmas and, to a lesser extent, Easter. Certainly, this competition between the men of different bike stands was evident after the war, but it probably also encouraged the spread and popularity of the street pictures during the conflict, something that was suggested to me by Lusi, the Christian woman I mentioned above.

One of the most spectacular scenes I ever witnessed where some of these energies and affective investments were exposed was in a short video clip that a stringer in Ambon showed me of Christian men on their way to fight the Muslims. Following a truck careening down the main thoroughfare and commercial hub of Ambon's A. J. Patty Avenue, the camera zooms in on a handful of young men with red head ties waving and gesticulating with their weapons. 
Pulling abruptly curbside, the truck pauses to disgorge the men, who jump out of its back, squat in the street, and scrawl slogans on its tarred surface with white paint-Nazareth, Ambon Mossad, Israel anti-Muhammed, Repoblik Maluku Sarane (sic), and a white, six-pointed star on a red background that subsumes the Christians' wartime identification with Israel within the red and white colors of the Indonesian flag. ${ }^{56}$

"Emosi!" was the word the stringer used to describe the outburst of youthful energy and aggression that we briefly saw on screen and that left me stunned. Akin to the Dutch word emotie, or emotion, from which it derives, emosi in Indonesia has a negative connotation. When it comes to emosi, the sense inevitably is that there is too much of it, indicating a lack of control and intense anger. In the case of the stringer, himself a Christian, the word expressed less a judgment than a straightforward appraisal of the situation, of just how revved up the young men had been when they set off to confront the Muslims. Similarly, following the stringer, the difference between the wartime graffiti and the banners temporarily suspended over urban streets that we also saw in some clips was that while the former was driven by emosi, the latter responded directly to specific events, such as actions on the part of the Indonesian Armed Forces (I. Tentara Nasional Indonesia, or TNI) in Ambon: "This is the result of the criminality of the TNI," accused one banner; "TNI belongs to Acang [the Muslim enemy]," declared another; still another threatened the then commander of the armed forces in Ambon, substituting his first name, Max, with that of the Muslim Prophet, "Muhammed Tamaela should be strung up and burned." ${ }^{57} \mathrm{My}$ invocation of emosi here and especially the clip that registers its inscription on one of Ambon's main arteries is because, more than any other, this scene conveyed to me with frightening clarity and force how much not only the wartime graffiti but also its companions in the streets, the Christian pictures, emerged and stood their ground as enormously charged, embattled artifacts, aggressive claims to territory, and as a highly defensive articulation of representational redress.

\section{Sighting the Street}

In his influential essay "The Rhetoric of the Image," Roland Barthes coins the term anchorage for the captions, titles, and other bits of text that rein in and reduce the myriad meanings and interpretations that any image may spawn, with the aim of circumscribing its significance. ${ }^{58}$ With respect to the Christian pictures, it is possible to see the array of material practices and artifacts, the sociality, masculine performances, and interpersonal dynamics, the personal and collective identities, the sense of God's estrangement, the drive to 
experiment and figure, and the explosion of emosi as constituting an anchorage that helped to channel the impact of the pictures in Ambon's wartime and postwar streets. My intention in using this term is not to circumscribe or, indeed, diminish the power of these images by reducing their impact to contextual considerations. Rather, anchorage allows me to marshal some of the connections-or, more actively, the force field-that help to account for the street pictures' undeniable potency by identifying some of the forces that fed and sustained them, including the aggression and territorial commitments that were folded into the pictures. Understood dynamically as a field of heterogeneous energies and palpable materialities, anchorage in Ambon's streets comprised the defensive locations of the guardhouses, the style and sense of threat presented by the bikers, their presence and performances at the edge of Christian neighborhoods, the sociality that converged on the borders of religiously marked urban areas and thickened during the conflict, the myriad inscriptions on the material surfaces of the city, the neighborhood pride and loyalties, the shared histories and shared enmities, and, during the time of my fieldwork, the then still recent experiences of the war.

I began this chapter with an account of how and why Protestants turned to painting Christianity in Ambon's streets and how doing so meant abandoning the long-standing antimaterialist and aniconic tradition of Calvinist Protestantism and how this new material commitment, animated by the desire to bring God into vision and up close, entailed dramatic adjustments to the Christian iconographic canon. As the Christian pictures moved out of homes and stores and became monumentalized in the postwar urban environment, they not only changed but opened themselves to the pressures, desires, and imaginations of the streets-despite the avowed commitment on the part of the painters to copying rather than transforming the Christian canon. It is these streets that, approached from several angles, I have tried to keep in view in this chapterfrom the characteristics of the key locations where the billboards and murals first arose, to the young men and biker groups who sponsored the pictures and the more diffuse Christian neighborhood-based sociality clustered around them, to the energies, desires, and expectations that suffuse these sites, keeping in mind also those of the multitudes who regularly passed by the pictures and saw how these conformed or did not conform to what Indonesians expect to see when they approach the entrance to a guarded neighborhood. ${ }^{59}$

In a thoughtful essay, Dilip Gaonkar singles out the rising significance of streets (along with slums), notably in the Global South, as the preeminent site where people congregate and where increasingly a kind of history is made: "The closing years of the last millennium and the opening years of the new millennium have witnessed the so-called people without history, or on the edges 
of history, storming the gates of history in the streets and squares everywhere: Tiananmen (Beijing, 1989), Azad (Tehran, 1979, and 2008), Tahrir (Cairo, 2011), Taksim (Istanbul, 2013), Maidan (Kiev, 2013) and elsewhere." ${ }^{60}$ To this list, Bundaran HI-Jakarta's huge roundabout in front of the iconic Hotel Indonesia built by Sukarno and the site of multiple student demonstrations and gatherings in 1998-might have been added. During the period of Reformasi, the spectacle and exuberant publicity of a panoply of new political, religious, and artistic forms and performative styles claimed the nation's streets as their recurrent stage. "Take to the streets!" was a recurrent battle cry among the country's young men and women who marched in the capital Jakarta and other Indonesian cities in 1998 and 1999, bravely stood off the army at often considerable risk to their own lives, occupied the parliament, and celebrated under Reformasi's hopeful banner when the downfall of the regime came about. ${ }^{61}$ In the years immediately following Suharto's downfall, a "visibility contest" took over. ${ }^{62}$ Streets across the nation became crowded with different groups-one more theatrical than the next-that contested and vied with each other for social, political, and economic stakes in postauthoritarian times: intellectuals, artists, and transgender people protesting antipornography and "pornographic action" laws; Islamic militants in white, yelling and waving weapons; or, further afield in wartime Ambon, ecumenical processions of Christians marching against forced conversions to Islam; the local branch of the national organization of Concerned Women gathered in front of the governor's office; people carrying fake coffins in protest of the imposition of civil emergency; Muslims demonstrating against the closure of the Laskar Jihad radio station; and so on.

Like many national histories, Indonesia's has for long been written from the perspective of the center, documenting its influence and reach, imposing a state-endorsed unity on the country's remarkable if depoliticized diversity (including religion) and channeling the ambitions of its huge citizenry. But Gaonkar suggests how, in recent times, the so-called people without history or at the edges of history may be coming out in multitudes, leaving their mark on major spaces of their respective nations and, at times, transforming them. ${ }^{63}$ When they break through the proverbial gates of history, they become part of it-as Jakarta's storied pemuda, several times over, have entered history since their canonization as a force of change following Indonesia's independence struggle.

But what happens when the impact is more marginal and ephemeral, when people at the edges of history remain outside of it, not entering and attempting to alter official history dramatically as in Tahrir or Tiananmen Square but more diffusely introducing change from below without, by and large, any awareness of doing so? Ambon offers just such an example of significant, if 
unwitting, change that began in the streets, was propelled by young men at the edge of authority and, certainly, the margins of history-the Protestant motorbike-taxi drivers who seized urban sidewalks and walls and subjected them to a vast, anxious work on appearances. To be sure, this example evidences the increasing role of the street in Ambon and Indonesia, as elsewhere, as an especially important site for significant sociopolitical transformation today. But what such a bottom-up history or, better, bottom-up visual history may also have to offer is an enhanced attunement to the affective intensities that animate the lifeworld of the street and, as such, bring us closer to some of the desires and motivations of those who congregate, act, and dream there. ${ }^{64}$

Besides the Christian street paintings, photographs of young men-whether taken during the Indonesian revolution, for a motorbiker group's documentation, or culled from my own archive of materials on Maluku-featuring individual men or groups of motorbike taxi-drivers, painted bike stands and walls, and urban neighborhoods and traffic took center stage in this chapter. The stylistic expressions they record, as I have tried to suggest here, come closest to men's highly performative, embodied practice, offering an avenue though which to tap the energies and affective investments of the street. Except when they are incorporated into photographs as backdrops for masculine performances, Ambon's street paintings do not provide the same kind of access in this regard. They do not show us as directly who the young men want to be as when they pose before the camera; as such they are even more mediated than such photographs-by the Christian iconographic canon, by the medium of paint and wall, by the significant departure from Calvinist tradition, by the street painters themselves, by fierce contests among different Christianities, and by a host of uncertainties, longings, and concerns. But, in other respects, they are as bottom-up as the young men's photographs, especially in how they bring us close to the heterogeneous imagination, the creativity, and wild experimentation that propelled the practice of figuration, as the billowing purple smoke enveloping one of Ambon's besieged landmark churches as Christ looks on from above, in the painting reproduced before this chapter, fantastically conveys. 